University of Massachusetts Amherst

ScholarWorks@UMass Amherst

Masters Theses 1911 - February 2014

1983

Patterns of bluestain discoloration and associated organisms in Japanese black and Scots pines on Cape Cod, Massachusetts.

Lorraine Beth Highley

University of Massachusetts Amherst

Follow this and additional works at: https://scholarworks.umass.edu/theses

Highley, Lorraine Beth, "Patterns of bluestain discoloration and associated organisms in Japanese black and Scots pines on Cape Cod, Massachusetts." (1983). Masters Theses 1911 - February 2014. 3514. Retrieved from https://scholarworks.umass.edu/theses/3514

This thesis is brought to you for free and open access by ScholarWorks@UMass Amherst. It has been accepted for inclusion in Masters Theses 1911 - February 2014 by an authorized administrator of ScholarWorks@UMass Amherst. For more information, please contact scholarworks@library.umass.edu. 


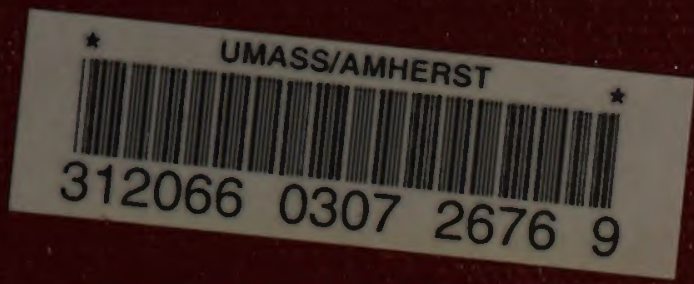

\section{FIVE COLLEGE DEPOSITORY}




\title{
PATTERNS OF BLUESTAIN DISCOLORATION AND ASSOCIATED ORGANISMS IN JAPANESE BLACK AND SCOTS PINES \\ ON CAPE COD, MASSACHUSETTS
}

\author{
A Thesis Presented \\ By \\ LORRAINE BETH HIGHLEY
}

Submitted to the Graduate School of the University of Massachusetts in partial fulfillment

, of the requirements for the degree of

MASTER OF SCIENCE

February 1983

Plant Pathology 


\section{PATTERNS OF BLUESTAIN DISCOLORATION AND ASSOCIATED ORGANISMS IN JAPANESE BLACK AND SCOTS PINES \\ ON CAPE COD, MASSACHUSETTS}

\section{A Thesis Presented}

By

LORRAINE BETH HIGHLEY

Approved as to style and content by:

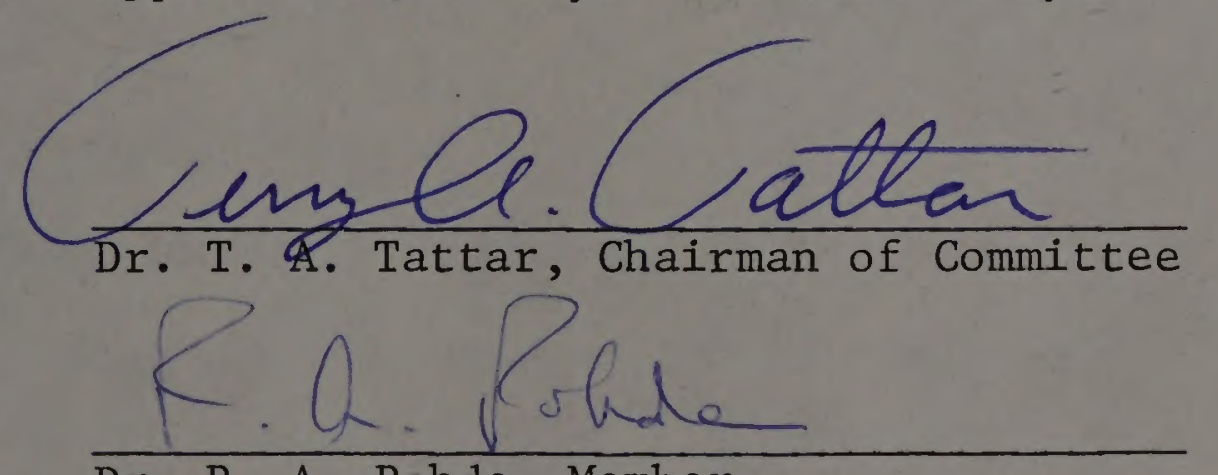

Dr. R. A. Rohde, Member
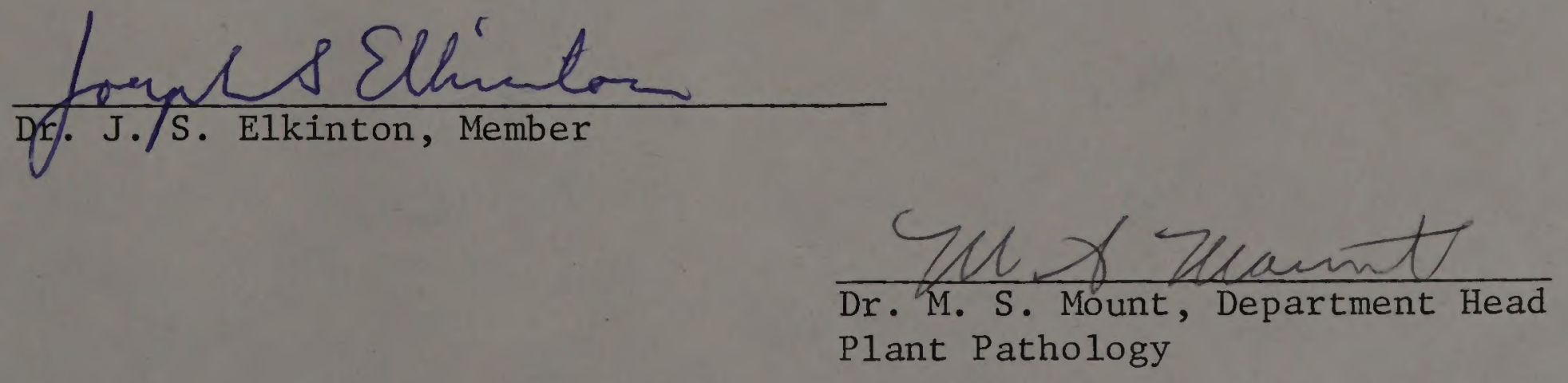
This manuscript is dedicated to my two grandmothers whom I loved and admired very much, both of whom died before its completion.

It is also dedicated to the Lord who is the giver of all knowledge, for only by His grace was this work possible. 


\section{ACKNOWLEDGEMENTS}

I thank Dr. Terry A. Tattar for his advice and assistance in all phases of this project. His positive attitude and continual encouragement were greatly appreciated. I also thank Dr. Richard Rohde and Dr. Joe Elkinton for their helpful suggestions and for serving on my committee.

I thank Mr. and Mrs. Richardson for generously providing lodging while on the Cape and Mr. Herb Philbrick and Mr. Walt Shaw for their tremendous assistance in locating and dissecting trees on the Cape. I thank Abby Cox for his cheerful assistance with laboratory work and the other members of the Shade Tree Laboratory staff for their assistance.

I would like to express my sincere appreciation to my officemate, Stan Kostka for his helpful critique of my manuscript. Special thanks go to Karen Rane for her helpful suggestions, neverending assistance, and invaluable friendship. Her presence helped to make this research so much more enjoyable.

Finally my deepest thanks go to my parents and family for their constant interest, support and understanding throughout this endeavor. 
ACKNOWLEDGEMENTS. . . . . . . . . . . . . . . . . iv iv

LIST OF TABLES. . . . . . . . . . . . . . . vi vi

LIST OF FIGURES . . . . . . . . . . . . . . . . v vii

INTRODUCTION. . . . . . . . . . . . . . . . viii

Chapter

I. LITERATURE REVIEW. . . . . . . . . . . . . . 1

Bark Beetle Vectors of Bluestain Fungi......... 1

Bluestain Fungi in Pines.............. 6

The Bluestain-Bark Beetle Association. . . . . . . . 12

Host Response to the Bluestain-Bark Beetle

Association. . . . . . . . . . . . . 14

II. MATERIALS AND METHODS. . . . . . . . . . . . 16

1981 Field Season. . . . . . . . . . . 16

1982 Field Season. . . . . . . . . . . . . 20

III. RESULTS. . . . . . . . . . . . . . . 23

Japanese Black Pines............. . . 23

Scots Pines. . . . . . . . . . . . . . . . 30

Isolations from Wood and Beetles......... 38

Inoculations of Pines. . . . . . . . . . . 42

IV. DISCUSSION .......................... 45

LITERATURE CITED. . . . . . . . . . . . . 51

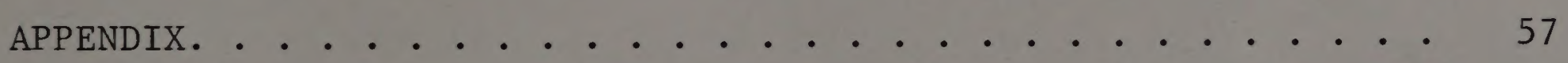




\section{LIST OF FIGURES}

1. Field plots of Japanese black pines and Scots pines located on Cape Cod, Massachusetts. . . . . . . . . . .

2. Typical cross-sectional views of bluestain discoloration patterns in lower bole of Japanese black pines. . . . . . .

3. Photograph of cross-section of lower bole of Japanese black pine showing bluestain discoloration pattern . . . . . . . . . . . . . . . . . . .

4. Photograph of cross-section of Japanese black pine at $30 \mathrm{~cm}$ below ground showing bluestain discoloration pattern... . . . . . . . . . . . . . . . 29

5. Typical cross-sectional views of bluestain discoloration patterns in lower bole of Scots pines. . . . . . . . . 35

6. Typical cross-sectional views of bluestain discoloration patterns in upper bole of Scots pines. . . . . . . . . 36

7. Photograph of cross-section of lower bole of Scots pine showing bluestain discoloration pattern. . . . . . . 37

8. Photograph of cross-section of upper bole of Scots pine showing bluestain discoloration pattern. . . . . 37

9. Typical vertical extent of bluestain discoloration in relation to range of attack of Ips $\mathrm{sp}$. and Dendroctonus terebrans and foliar crown symptoms of Scots pines. . . . . . . . . . . . . . . . . . 39

10. Conidiophores of Leptographium . . . . . . . . . . . . . . 41

11. Typical host response of Japanese black pine and Scots pine to Leptographium inoculation . . . . . . . . 


\section{INTRODUCTION}

Considerable mortality of Japanese black pines (Pinus thunbergii) and Scots pines (Pinus sylvestris) has occurred on Cape Cod over the past several years. Death of these trees was first observed by arborists and homeowners on Cape Cod, Massachusetts and brought to the attention of Becker (1972), who attributed the death of the trees to the girdling effect of the black turpentine beetle (Dendroctonus terebrans). While the black turpentine beetle excavates its gallery in the inner phloem it inoculates the sapwood with a bluestain fungus. This fungus has been identified as Leptographium (Tattar, et a1., 1980). Trees are capable of surviving attack by the black turpentine beetle but decline and die when the fungus invades the sapwood rendering it nonfunctional (Nelson and Beal, 1929). Similar bluestain-bark beetle associations have been reported in other areas of the United States (Basham, 1970; Bramble and Holst, 1940; Craighead, 1928; Nelson, 1934). This is the first report of this type of association occurring in the Northeastern Unites States on Japanese black pines and on Scots pines. The black turpentine beetle is a native to the Southeastern United States. It occurs on Cape Cod which is the northernmost extent of its range.

This research is a preliminary study of the black turpentine beetle-bluestain association associated with Japanese black pines and Scots pines on Cape Cod. The objectives of this research were to:

(1) determine the pathogens associated with mortality of Japanese black pines and Scots pines attacked by the black turpentine beetle; (2) to 
C H A P T E R I

\section{LITERATURE REVIEW}

\section{Bark Beetle Vectors of Bluestain Fungi}

Bark beetles. Beetles belonging to the Genus Dendroctonus, Family Scolytidae singularly confine their destructive activity to the inner bark of trees. Usually the first sign of a beetle infestation is the appearance of pitch tubes on the tree (Becker, 1972; McCambridge, et al., 1979; Pollack, 1977). Pitch tubes are lumps of resin exuded at the entrance point of the beetle. After initial entry the tubes appear yellowish-white but as the beetle mines the gallery, the frass mixes with the pitch causing a reddish-brown granular tube. Dendroctonus beetles are selective about the portion of the tree chosen for construction of an egg gallery. Some species invade the main trunk, others the buttress roots and others attack large limbs (Knight and Heikenen, 1980). D. terebrans, the black turpentine beetle, attacks the lower bole and buttress roots of pines (Becker, 1972; Clark, 1970; Godbee and Franklin, 1976; Smith and Kowal, 1968; Tattar et a1., 1980). Smith and Kowal (1968) found three types of galleries occurring on the roots of slash pine, Pinus elliottii. Abortive galleries caused by initial unsuccessful attacks were followed by attacks resulting in feeding galleries. Egg galleries, the third type, occurred only on trees possessing both abortive galleries and feeding galleries.

Dendroctonus spp. excavate their galleries in the fresh phloem between the outer bark and the sapwood (Knight and Heikenen, 1980). Eggs 
are laid in the egg gallery and upon emergence the larvae mine from the egg gallery into the adjacent phloem. Pupal chambers are formed at the end of each larval gallery and after pupation the young adults emerge to attack new trees (Whitney, 1971). The shape of the gallery varies according to the beetle species. Some species, such as $\underline{D}$. frontalis, the southern pine beetle and $\underline{D}$. ponderosae, the mountain pine beetle, lay eggs individually in niches along the egg gallery. These larvae emerge and feed individually, forming winding galleries in the phloem (McCambridge, et al., 1979; Reid, 1962). The black turpentine beetle, D. terebrans, lays eggs in a large linear group along one side of the gallery. These larvae feed gregariously killing large patches of phloem (Becker, 1972; Smith, 1957).

The death of pine trees infested with bark beetles has not been attributed solely to the beetles (Craighead, 1928; Davidson, 1958; Mathre, 1964; Robinson, 1962). A bluestain fungus is seen in constant association with the beetles (Leach, 1934; Rumbold, 1931, 1936, 1941). Bark beetles come in contact with the bluestain fungi growing in their galleries. Mycangia, which are specialized pouches on the beetles, are used to transport the fungi (Barras and Perry, 1971; Barras and Taylor, 1973; Whitney and Farris, 1970). The adults introduce the bluestain fungi into the egg gallery. As the larvae mine they do not transport the fungi but their tunnels provide an unobstructed avenue with improved gas-exchange for the fungus to grow. The fungus, after colonizing the larval tunnels, will invade the brown discolored phloem adjacent to the galleries before invading healthy phloem or xylem (Whitney, 1971). 
Dendroctonus spp. are host selective, attacking predominantly pines and occasionally other conifer species. Because of their attack on wounded or weakened trees they have been considered "secondary" invaders (Knight and Heikenen, 1980). When populations are high and conditions are favorable these beetles may attack and kill large numbers of healthy trees. Speculations have been made as to why these beetles can become "primary" attackers. Outbreaks may be preceded by periods of drought (Craighead, 1925; Craighead and St. George, 1940; Hopping and Mathers, 1945; Reid, 1962; St. George, 1930) and it is believed that drought is sufficient to predispose the tree to beetle attack. Hetrick (1949) reported a southern pine beetle, $\underline{D}$. frontalis, outbreak not preceded by a drought period, but rather by a period of excessive rainfall. He proposed that both conditions produce similar results by interfering with the normal functioning of the roots. Other factors causing injury to the roots also contributed to making the tree more attractive to the beetle. Lightning injury that followed the trunk of the tree to the roots and infestations of Armillaria mellea were also predisposing agents. Hetrick (1949) sees this as evidence that root damage is the key to initiating beetle attack and any circumstances that injure the roots should be included. Japanese black pines and Scots pines are suitable hosts for the black turpentine beetle. Becker (1972) noted the dry soil and hard pan associated with each tree attacked by the beetle, and concluded that they both predisposed the trees to attack. Sartwel1 and Stevens (1975) reported severe infestations of $\underline{D}$. ponderosae in undisturbed stands during periods of both normal and deficient rainfall. 
Most Dendroctonus beetles attack individual trees in large numbers. This extensive attack of individual trees results from the production of an aggregating pheromone produced by the beetles after attacking the tree (Coster, et al., 1977; Godbee and Franklin, 1976; Person, 1960, Vite and Crozier, 1968; Wood and Vite, 1961). D. terebrans differs from the other members of the genus in that initial attacks are few, confined to the lower $45 \mathrm{~cm}$ and in themselves may be fatal (Smith, 1957). The mass attack of trees by Dendroctonus sp. is dependent on the success of the initial attack (Vite, 1961).

Several species belonging to this genus have caused considerable loss of timber. The southern pine beetle periodically reaches epidemic levels causing extensive death of shortleaf pines (Bramble and Holst, 1940). The mountain pine beetle and western pine beetle, both native to the western states, attack and kill millions of trees each year, during epidemics lasting 6 to 8 years (McCambridge, et al., 1979; Pollack, 1977). The black turpentine beetle, native to the southeastern states, attacks loblolly, slash, and shortleaf pines. This beetle rarely kills a large percentage of the stand at one time and its damage often goes unnoticed; however, attacks occur throughout most of the year and as much as $20 \%$ of a stand can be killed in one season (Smith, 1975). This beetle may have always been on Cape Cod but only recently has become a pest to Japanese black and Scots pines growing there (Becker, 1972; Tattar, et al., 1980).

Engraver beetles. Beetles belonging to the Genus Ips, Family Scolytidae are "secondary" bark beetles. Bluestain fungi are also vectored by 
beetles belonging to this genus. Characteristic bluestain discoloration appears in the wood following attack by these beetles (E11is, 1939; Mathre, 1964; Rumbold, 1931). Most species in this genus attack recently killed trees, but some are more aggressive, attacking tops of trees, limbs, or young trees (Berisford and Franklin, 1971; Mathre, 1964;

Rudinsky, 1962). As in the genus Dendroctonus, these beetles may, under certain conditions become numerous enough that they will attack vigorously growing pines (Nelson, 1934). Attacks by Ips occur on trees predisposed by other factors. Pines infested with Dendroctonus sp. are attractive and Caird (1934) observed Ips colonizing these trees within 3-4 days of Dendroctonus infestations. These two genera often occur together, each colonizing a different portion of the tree. Ips sp. colonize the bole from the upper limit of Dendroctonus sp. galleries to the leader (Caird, 1934).

Initial attack is made by the male Ips. After excavating a nuptial chamber, between 1-3 females enter and individually mine their own galleries radiating outward from the nuptial chamber. These galleries are kept clear of frass. Small accumulations of this brown frass outside the entrance holes are signs of Ips sp. infestations. The female lays eggs in small niches along the gallery and as the larvae emerge they mine away from the gallery feeding on the fresh phloem. After pupation the young adults feed a short time longer before emerging (Anderson, 1948; Knight and Heikenen, 1980).

Attack by Ips beetles is concentrated on a few trees rather than lightly infesting a large number of trees. After the initial beetles 
attack the tree, a pheromone is emitted and a mass attack occurs (Anderson, 1948; Rudinsky, 1962).

\section{Bluestain Fungi in Pines}

Patterns of bluestain discoloration. Bluestain discoloration occurs in pines following attack by bark beetles (Craighead, 1928; Davidson, 1955, 1978; Bramble and Holst, 1940; Kaarik, 1960; Nelson and Beal, 1929; Robinson-Jeffrey and Grinchenko, 1964; Robinson, 1962). The bark beetles vector the fungi which cause the discoloration. This discoloration may appear along the galleries within a week of attack (Nielson and Beal, 1929). The bluestain is caused by a number of different fungi and is due to dark hyphae growing in the wood. Although the hyphae are brown they appear blue when growing in the wood (Lagerberg, Lundberg and Melin, 1927). They grow primarily in the parenchymous cells of the wood rays where they pass from cell to cell through the pits. The hyphae break off and invade the tracheids and resin ducts through the bordered pits, occasionally penetrating cell walls (Nelson, 1929). As the fungus invades the ray tissue the patterns occurring in crosssection are wedges extending from the beetle galleries to the heartwood (Harvey, 1979; Nelson, 1929; Von Shrenk, 1903). Rumbold (1931) reported Ceratostomella pini growing in longitudinal streaks on the surface of the sapwood from the galleries. These areas vary considerably in size and shape depending on their age and the extent of beetle attack, often the smaller areas expand and coalesce to form large patches (Nielson and Beal, 1929; Harvey, 1979; Von Shrenk, 1903). These patches often have 
a black granular appearance from the numerous sclerotia and perithecia growing there (Mathre, 1964; Rumbold, 1931). The amount of bluestained sapwood varies depending on the length of time since beetle attack, the intensity of the attack, and the size of the tree attacked. Harvey (1979) found that smaller diameter trees, having a lower sapwood to heartwood ratio had a smaller proportion of stained wood. The percentage of bluestained wood increased with time. He hypothesized that the higher the density of beetle attack, the larger the volume of stained wood.

Nelson (1929) inoculated trees to determine the amount of bluestained wood necessary to kill trees and found that some trees had as much as $80 \%$ of their cross-section bluestained yet they were able to transport sufficient water to keep the foliage alive. From this he concluded that the entire cross-section must be bluestained for death to occur. Robinson (1962) followed the disease progression in lodgepole pine and found that initial attack by $\underline{D}$. ponderosae caused an early bluestain to appear but death of the tree did not occur until the sapwood was completely stained by another bluestain fungus vectored by Ips spp.

The discoloration patterns in the phloem and cambium were studied by Molnar (1965). After attack by the western balsam bark beetle on Alpine fir, a light brown discoloration appeared in the phloem around the galleries. These areas first turned dark brown and eventually became bluestained. Reid et al. (1967) noted a similar response in lodgepole pine attacked by $\underline{D}$. ponderosae. 
Succession of microorganisms. The response of a tree to a wound has been studied by Shigo (1967). His research has resulted in the knowledge of a succession of microorganisms occurring after wounding. He states that bacteria and nonhymenomycetous fungi are the first to invade following wounds, these are followed by hymenomycetous fungi. Basham (1959) extensively studied the progression of deterioration in Balsam fir. He states that successions are no longer the exception, they appear to be the rule. He found that the sapstain and sap rot are not the result of one fungus as originally thought but rather a succession of fungi, occurring in a regular sequence. A definite relationship occurred between the stage of deterioration and the specific fungi present. He presents the hypothesis that the sequence of fungi is the result of a dependence upon changes in the wood substrate. The later fungi are unable to colonize sapwood because the $\mathrm{pH}$ or moisture content is too high. The primary invader of the tree following beetle attack is a yeast (Whitney, 1971); these form discolored patches of cambium around the galleries and can only invade the wood $1 \mathrm{~mm}$ beneath the phloem. The presence of a yeast immediately following attack was reported in studies on shortleaf pines (Holst, 1936) and lodgepole pines (Whitney, 1971). A succession of microorganisms was also found following attack by Dendroctonus beetles. Bramble and Holst (1940) recorded a complex invasion involving several fungi occurring within a short period of time. Primary invaders played an active role in aiding the beetles in causing death. Dacryomyces sp. and Zygosaccharomyces pini both invade first but are unable to penetrate the sapwood as far as 
Ceratostomella pini which invades later. Secondary invaders, Tricho$\underline{\text { derma }}$ and Monilia appear after conduction has stopped, when the foliage has turned brown and are not important in the death of the tree. Caird (1935) reported similar results and also noted that bluestained wedges did not appear until late in the disease cycle.

Succession of bark beetles and microorganisms. Several beetle genera have been associated with bluestained pines. The order in which these beetles invade an individual tree is dependent upon their characteristics. Dendroctonus beetles attack and weaken a tree making it attracto Ips beetles (Caird, 1935). A complex succession of organisms has been observed attacking lodgepole pines, and a specific relationship between the bark beetles and their corresponding bluestain recorded (Robinson, 1962). She found that $\underline{D}$. ponderosae is the first to attack, introducing yeasts and a primary bluestain fungus, Ceratocystis montia. These organisms weaken the tree and Ips sp. vectoring Leptographium sp. attack the upper crown resulting in death of the tree and completely bluestained sapwood.

Taxonomy. The fungi causing bluestain in wood are of considerable pathological and economical importance. Classification of these fungi has been difficult because the perfect stages are not always known, are rarely encountered in nature, or are difficult to produce in culture. Controversy exists among mycologists as to the best method for classifying these fungi. Some place emphasis on conidial characteristics (Davidson, 1935) while others feel that those characteristics are so 
varied and emphasis should be on the characteristics of the perfect states (Hunt, 1956; Parker, 1957; Robinson-Jeffrey and Grinchenko, 1964). The genus Leptographium (Deuteromycetes, Moniliales) consists of fungi with darkly pigmented conidiophores bearing a complex penicillate sporogenous apparatus. There has been disagreement on the taxonomic classification of fungi in this genus. These fungi were first included in the genus Scopularia which was described and illustrated by Preuss in 1851 (Shaw and Hubert, 1952). In 1927, Lagerberg, Lundberg and Melin erected a new but very closely related genus, Leptographium, because of the inavailabilty of a Scopularia culture for comparison. The genera $\underline{\text { Hantzschia }}$ and Scopularia have been considered synonymous to Leptographium by some mycologists and in 1952, Shaw and Hubert assigned them all to the genus Leptographium (Shaw and Hubert, 1952).

Bluestain fungi have also been classified according to their ascomycetous perfect states when found (Wright and Cain, 1961). Grosmann found a perfect state associated with a Leptographium imperfect state which she named Ceratostomella penicillata (Grosmann, 1932). Goidanich later established Grosmannia to accommodate Grosmann's and other similar fungi. Siemaszko preferred the name Ophiostoma for this genus. Parker (1957) found another perfect state of Leptographium which differed from those in the genus Grosmannia and constructed the genus Europhium to include it. Hunt (1956) combined all these genera into the genus Ceratocystis thereby avoiding the difficulty in classifying those species which appear intermediate in characteristics.

In 1953, Hughes proposed an experimental system of classification 
for hyphomycetes which placed emphasis on the method of spore production. When reviewing the Leptographium complex, Kendrick (1961, 1962) noted fungi with three different methods of spore production. These were separated into distinct genera. Phialocephala was established to include fungi possessing phialides and producing conidia in a basipetal succession. Those fungi producing conidia in a sympodial manner, the conidia pushed singly out of the apex of the conidiophore, and the successive new growing point developing to the side of the previous terminal conidium were transferred to the genus Verticicladiella. The third type of conidial production, annellosporous characterized Leptographium. These fungi possess sporogenous cells which produce the first conidium terminally leaving an annular scar when pushed off. The repetition of this process increases the length of the sporogenous cells which bears as many annellations as it has produced spores.

Reconstruction of this genus has resulted in confusion in the literature. Leptographium and Verticicladiella are two similar genera causing bluestain discoloration in conifers. Much of the early work on bluestain discoloration by Verticicladiella was attributed to Leptographium (Goheen and Cobb, 1978; Leaphart and Gil1, 1959; Leaphart, 1960; Wagner and Mielke, 1961).

The genus Leptographium is characterized by mononematous conidiophores, lightly pigmented when young but becoming brown with age. The penicillate conidiophores possess 1-6 metulae, the last of which bear numerous conidiogenous cells. These cells produced unicellular, hyaline, elongate annellospores which accumulate in a mucilaginous mass at 
the tip of the conidiophore (Barras and Perry, 1971; Barnett and Hunter, 1972). In culture, the fungus develops rapidly, both aerial and submerged mycelium appearing hyaline at first and darkening with age. The conidiophores form within a few days and white mucus heads, later turning honey colored rapidly cover the plate giving it a speckled appearance (Barras and Perry, 1971).

\section{The Bluestain-Bark Beetle Association}

Craighead (1928), Rumbold (1931, 1936), and Kaarik (1960) have found that beetles belonging to the genera Dendroctonus and Ips transport bluestain fungi and inoculate their host during attack. Due to this constant association a relationship between the two seems highly probable. In mutualism, both symbiotes benefit from the association. Graham (1967) termed the mutualism between bark beetles and bluestain fungi ectosymbiosis. This is a symbiosis in which the microorganism carries on its active function when dissociated from the vector. The fungi are carried on external parts of the beetle's body and/or in specialized pouches, called mycangia (Barras and Taylor, 1973; Leach, 1934). Bluestain fungi, mainly species of Ceratocystis and imperfect fungi in the genus Leptographium have sticky spores for mechanical transport by the insects (Lagerberg, Lundberg and Melin, 1927; Whitney and Farris, 1970). In the host tissue the fungi grow in the beetle galleries, both conidiophores and perithecia, when present, are embeded in the gallery walls (Leach, 1934).

After initial investigations, Nelson and Beal (1929) concluded that 
the girdling effect by the beetles was insufficient to cause the death of the trees. They recognized the bluestain fungi as potentially important in altering the host condition. Leach (1934) presented evidence of a vector relationship and suggested a type of symbiosis, noting the benefits derived by the fungus, but unclear on the benefits derived by the beetles. Bramble and Holst (1940) supported this type of relationship. They noted the beetles'mining activity and inoculation of the wood but emphasized the importance that the fungi had on the stoppage of water conduction. The fungi helped to lower the moisture content of the tree which was necessary for successful development of the beetle broods. Reid (1961) noted a correlation between the reduction in water content, brood development and presence of bluestain fungi. The greater the number of successful beetle galleries, the lower the amount of functional xylem. Trees with many successful galleries had a low sapwood moisture and the xylem in those trees later became bluestained. He could not determine a cause and effect relationship.

Despite their constant association, both the fungus and the beetle can exist and develop independently (Kaarik, 1960). Yearian (1972) successfully reared three species of Ips beetles on fungus-free logs. Hetrick (1949) observed the southern pine beetle infesting trees and developing healthy broods without the association of the fungus. Some researchers have proposed that the fungus may have an inhibitory effect on the developing brood (Barras, 1970). Franklin (1970) showed that adult beetles and larvae would not mine into bluestained areas. The bluestained inner bark may be nutritionally unsuitable as a result of 
the reduction of carbohydrates (Barras and Hodges, 1969; Mathre, 1964).

Yeasts are commonly associated with bark beetles and bluestain (Caird, 1935; Holst, 1936; Leach, 1934). A mutualistic relationship may also be occurring between these organisms but insufficient information is known to be sure (Callaham and Shifrine, 1960). It has been suggested that the yeasts may supply essential vitamins or other nutrients for the fungi (Callaham and Shifrine, 1960; Rumbold, 1941).

\section{Host Response to the Bluestain-Bark Beetle Association}

The death of pines infested with bark beetles and bluestain fungi has been attributed to the blockage of water transport (Caird, 1935; Mathre, 1964; Nelson, 1934). Bluestain fungi are found growing primari1y in the water conducting tissue in the xylem and dye studies have shown these areas to be nonfunctional (Caird, 1935). Several hypotheses on how the fungi affect conduction have been proposed. The most widely accepted explanation is the aspiration of tori resulting from the fungi invading the ray paremchyma cells (Nelson, 1934). Bramble and Holst (1940) suggest a blockage of the sapwood by resin released following fungal wounding. Death of Alpine fir has been attributed to phloem and cambial necrosis. Sufficient wounding, however, is necessary for individual necrotic lesions to coalesce (Molnar, 1964).

The defense mechanisms employed by the tree following attack by bark beetles have been studied. In conifers, the resin canal system is utilized in defense. A primary flush of resin results following wounding and many bark beetles are tolerant of this. Some (Dendroctonus 
$\underline{\text { valens }}$ and $\underline{D}$. terebrans) thrive in this resinous tissue and modify their tunneling activity to regulate the amount of resin in their gallery (Berryman, 1972).

- Berryman (1972) observed a hypersensitive response occurring in trees infested with bark beetles. This response involved a degradation of living cells and subsequent release of inhibitory compounds in areas surrounding the infection site. Since it occurred in living cells in advance of fungal invasion, this response appeared to be a reaction to fungal invasion rather than wounding. Resin substances then impregnated this necrotic area and served as a mechanical barrier to the pathogen (Berryman, 1972; Shrimpton and Whitney, 1967). 


\section{H A P T E R II}

MATERIALS AND METHODS

\section{Field Season}

Field observations. Observations made during the first field season, from April through September, on Cape Cod, Massachusetts were in several different locations (Figure 1). Field plots of Scots pines were 1ocated in Goodwill Park, Falmouth and in Barnstable at the Cape Cod Community College. Japanese black pine field plots were located on Penzance Point in Woods Hole. Scots pines were growing in forested areas located $2.5-3.0 \mathrm{~km}$ from the ocean, in contrast to Japanese black pines that were growing in ornamental plantings within $15-45$ meters of the ocean. Plots were chosen on the basis of mortality and amount of black turpentine beetle attack. All trees within the plots were observed periodically from candle elongation to early fall. Trees exhibiting chlorotic or brown crowns were first examined in the field. Diameter at breast height, crown conditions and number of pitch tubes were recorded. Trees were felled using a chain saw. A vertical cut extending the length of the tree was then made through the bark to aid in aligning the sections. Dissection was done by making $30 \mathrm{~cm}$ cross sections of the lower stem. Sections were examined to determine any xylem discoloration patterns. Sections were brought to the laboratory and isolations made (see Isolation from Wood). As the season progressed, the technique was modified to reduce the amount of wood being transported. Discs $5 \mathrm{~mm}$ thick were cut at $30 \mathrm{~cm}$ intervals. Sections were taken se- 


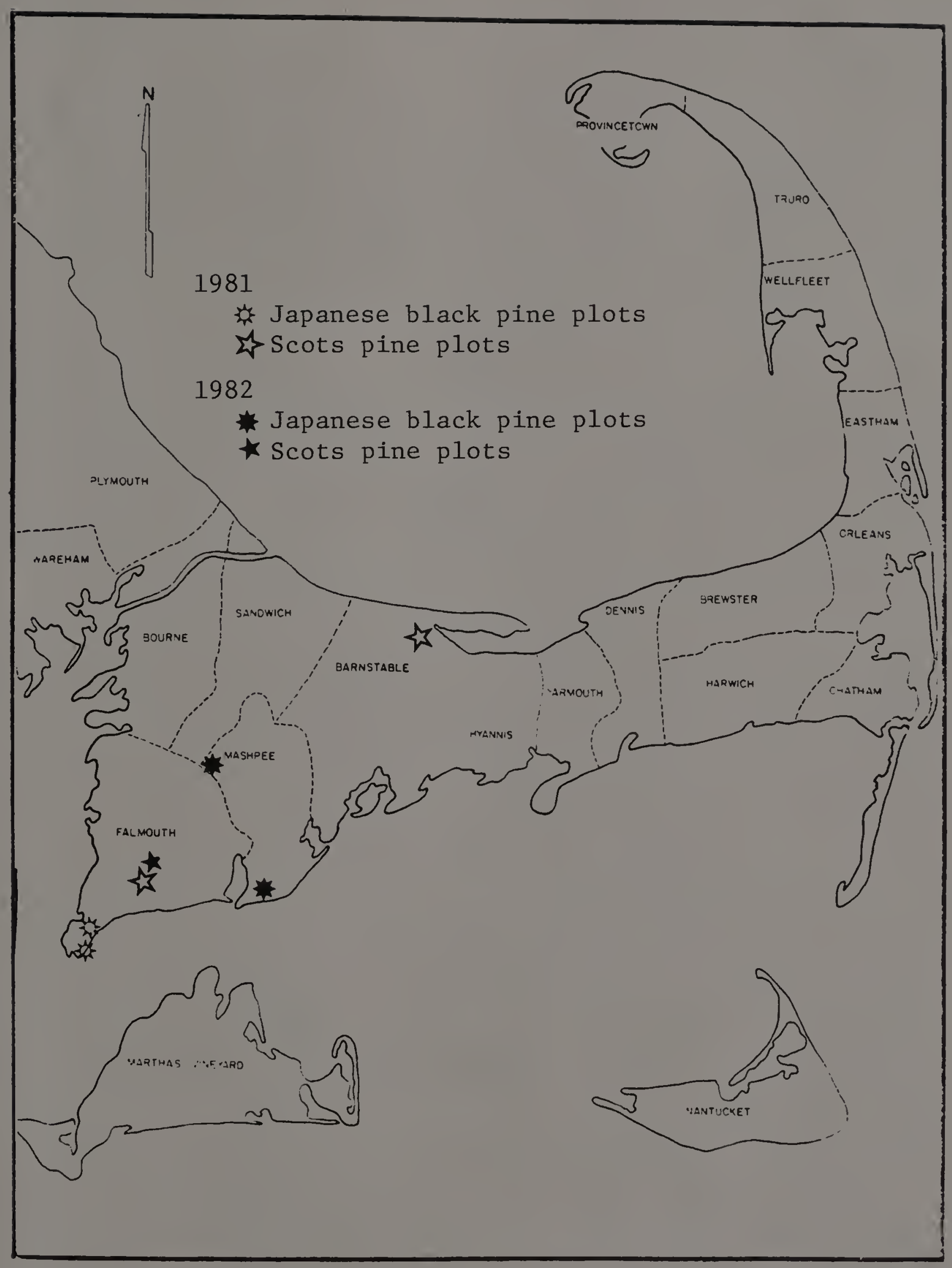

Figure 1. Location of field plots of Japanese black pines and Scots pines on Cape Cod, Massachusetts. 
quentially from the base to the crown until the bluestain discoloration ended (Bramble and Holst, 1940).

Patterns of bluestain discoloration. Log sections to be examined were returned to the laboratory and examined immediately or stored at $5^{\circ} \mathrm{C}$ to retard any additional growth of the organisms. Preliminary records of the bluestain discoloration were made by photographing each section. This method was later eliminated and the discoloration patterns were recorded by tracing onto clear acetate. Traced patterns were identified by the tree number and the height of the section above the ground. Age of the tree and growth rate were also determined by counting annual rings and measuring the number of rings per centimeter.

Microbial isolation from wood. Isolation was accomplished initially by splitting the section with an axe and mallet and subsequently removing sections of wood from the exposed surface with a sterile wood gouge. Isolations were made from both discolored and clean wood. Wood chips were placed on $2 \%$ potato dextrose agar (BBL) and incubated at room temperature.

To determine the position of the microorganisms involved a more precise technique described by Caird (1935) was used. A rectangular piece of wood, $2.5 \mathrm{~cm}$ thick, including all annual rings from the bark to the pith, was cut from each cross-sectional disc. Wood pieces were within the same vertical plane. Isolations were made by splitting the block part-way with a sterile scalpel and prying to complete the split without touching the area where isolations were being taken. Isola- 
ions taken from every fifth ring toward the center continued until a point four or five rings after the discoloration ran out. Chips of wood, $1 \mathrm{~cm}$ long, taken from the exposed face were placed on $2 \%$ malt agar (Difco) and incubated at room temperature.

Microbial isolations from beetles. Cultures were obtained from black turpentine beetles picked singly from infested trees. Half of the beetles were sterilized by placing them in $10 \%$ chlorine bleach for one minute, the other half were left unsterilized. Both sterilized and nonsterilized beetles were allowed to walk over the agar and crushed beetles were placed on $2 \%$ malt agar. Cultures were also obtained from eggs, larvae and clumps of frass collected in the same manner from infested trees and placed on malt agar.

Inoculations of pines. Inoculations of healthy Scots pines were made on trees growing in regions where the black turpentine beetle was absent. Test plots were located in the Mt. Toby Experimental Forest, Leverett, Massachusetts, about $300 \mathrm{~km}$ northwest of the known natural range of the black turpentine beetle. Five Scots pines averaging $25 \mathrm{~cm}$ diameter at breast height were inoculated with isolates of Leptographium recovered from the bluestained xylem in dying Scots and Japanese black pines on Cape Cod. Trees were inoculated using the cork borer method described by Molnar (1965). Inoculation sites were located $90 \mathrm{~cm}$ above ground and preparation involved scraping off the outer bark in a $7.5 \mathrm{~cm}$ square with a sterile knife. A sterile $1.0 \mathrm{~cm}$ diameter cork borer was then used to punch holes through the remaining bark and phloem into the sap- 
wood. Twelve to fifteen holes were made at each site. The bark plug was removed and an agar plug of a Leptographium ioslate grown on malt agar for two weeks was inserted in the hole. The inoculation site was covered with moist cotton and wrapped with black polyethylene sheeting. Each tree was inoculated at three sites, two areas were inoculated with two different isolates of Leptographium and the third with sterile agar to serve as a control.

\section{Field Season}

Field observations. Observations during the second field season were focused on healthy trees as well as trees in early stages of decline. Four field plots were chosen in late winter on the basis of two criteria: (1) the trees were growing in an area of expanding black turpentine beetle infestation, and (2) they were also in various stages of decline. These plots were located in areas with large populations of Scots and/or Japanese black pines and were more accessible than the plots the previous season. Scots pine plots were located in Goodwill Park, and in the Falmouth Town Forest, both were forested sites about $2.5 \mathrm{~km}$ from the ocean. Japanese black pines were located at a wholesale nursery and at a nature reserve in Falmouth. These plots were 1ocated in unmanaged groves of overgrown nursery stock, in contrast to Japanese black pine plots the 1981 season which consisted of specimen trees in residential plantings. Consequently, I was able to observe and dissect healthy trees and trees in early stages of decline at the nursery in 1982. Crown condition and number of pitch tubes were record- 
ed on all field plots. Observations were made biweekly from candle elongation to early fall. Two to four trees were dissected at each observation date. The trees were dissected as previously described.

Patterns of bluestain discoloration. Patterns were traced as previously described. Each section was macroscopically examined by carefully removing the bark and exposing the beetle galleries and bluestain discoloration in the outer sapwood. To quantify the amount of bluestain in each section, the circumference of each cross-sectional disc was measured and the amount of the circumference that was bluestained was measured. Only bluestained sections that extended to the phloem were included. The amount of circumference mined by the beetle was determined by measuring the width of all the galleries present on the $5 \mathrm{~cm}$ thick cross-sectional disc.

Microbial isolations from wood and beetles. Isolation techniques used during the 1981 field season were employed. Isolations were made from the phloem and inner bark directly adjacent to the galleries and several mm away.

Inoculations of pines. Inoculations were made on Scots and Japanese black pines on Cape Cod. These trees were growing adjacent to trees naturally infested by the beetle in Falmouth. These trees consisted of six Scots pines averaging $25 \mathrm{~cm}$ diameter breast height and five Japanese black pines averaging $12.5 \mathrm{~cm}$ diameter breast height. Lower boles were sprayed with a $1 \%$ Lindane emulsion spray (Becker, 1972) to protect the trees from beetle attack. A sterile knife was used to 
wound the trees by making an upward slit $2 \mathrm{~cm}$ long through the inner bark to the phloem/sapwood interface. Six to eight wounds were made in a $7.5 \mathrm{~cm}$ square. Inoculum consisted of Leptographium sp. grown on $2 \%$ malt agar (Difco) at room temperature for two weeks. Each tree had two inoculation sites, one inoculated with a Leptographium sp. isolate, the other with sterile agar to serve as a control. Sites were covered with moist cotton and wrapped with black polethylene. 
RESULTS

\section{Japanese Black Pine}

Field observations. Japanese black pines that were observed during the 1981 field season were growing in ornamental plantings, were between 25 to 30 years old and had a good growth rate, averaging 2 to 5 growth rings per $\mathrm{cm}$. The progression of foliar symptoms, always preceded by the attack of the black turpentine beetle, was rapid, healthy, green trees turning completely brown within 2 to 3 months. Needles throughout the entire crown first turned pale green, then chlorotic and then brown in rapid succession. Browning of trees occurred throughout the year. Dead needles did not drop until the following season.

Stages of disease progression were classified by the foliar symptoms into four foliar categories: (1) Green, (2) Green/chlorotic, (3) Chlorotic/brown, (4) Brown. The green crown category included trees with dark green, healthy needles. The green/chlorotic crown category included trees with needles first beginning to yellow, the entire tree having a light green hue. The chlorotic/brown crown category included trees with chlorotic needles beginning to turn brown, the entire tree having a golden color. The number of trees in the green crown category was low since my plot included only high value ornamental trees and only trees with advanced symptoms could be dissected during the 1981 field season. The green/chlorotic crown and chlorotic/ brown crown categories are transition stages. Only being able to ob- 
serve these trees once every two weeks was a disadvantage in studying these stages, because of the rapid rate of disease progression. It was also a disadvantage not being able to dissect most trees before they reached the brown stage.

Dying Japanese black pines usually had relatively low numbers $(\leq 10$ pitch tubes per tree) of pitch tubes on the lower bole. Black turpentine beetle attacks were frequently found on the buttress roots of trees with no other visible above ground pitch tubes. Another sign of black turpentine beetle infestation was frass around the bottom of the tree. Ips beetles were also found attacking these trees. Beetle activity varied according to the stage of decline. Green trees attacked by the black turpentine beetle had no Ips beetles present. There was a substantial increase in Ips activity as the crown condition declines. A similar correlation was observed between black turpentine beetle activity and foliar symptoms (Table 1 ).

During the 1982 field season, early symptoms of black turpentine beetle attacked trees were observed more closely. Two different early symptoms were noted: (1) trees with buds that broke dormancy but browned up before the new needles fully expanded and chlorosis first appeared on the candles of these trees; (2) trees in which the buds did not break dormancy and chlorsis occurred on the old needles throughout the crown.

Patterns of bluestain discoloration. An apparent relationship was found between the circumferential bluestain discoloration in the xylem and the crown symptoms (Table 1). Trees attacked by the black turpentine 


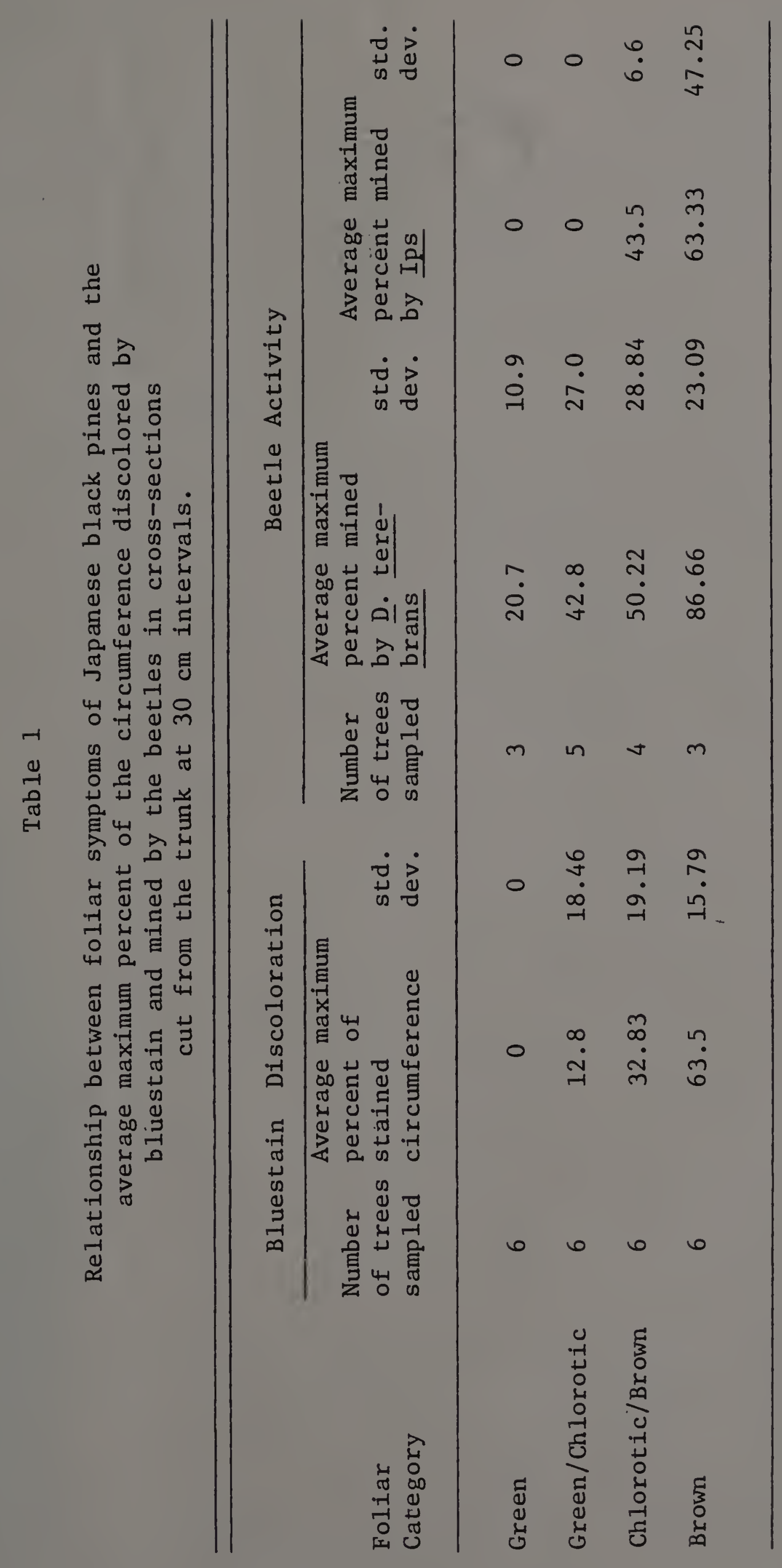


beetle and displaying green crowns had no bluestain discoloration in their xylem. There was a direct relationship between the percentage of bluestained circumference and the crown condition. Trees in the brown crown category possessed the highest percentage of circumferential bluestain. The vertical length of the bluestained discoloration extended slightly higher than the area of beetle attack (Table 2). A direct relationship was also observed between the vertical length of the bluestain and the crown condition. A notable increase in the height of discoloration occurred between the transition stages (green/chlorotic and chlorotic/brown) and the brown crown category.

The pattern of bluestain discoloration seen in Japanese black pines was typically a wedge-shaped pattern (Figures 2,3). Bluestained wedges radiated inward from the cambium and were associated with areas of beetle attack. Trees cut in cross-section also exhibited resin soaked xylem in wedges and these also surrounded beetle galleries. In addition, the Japanese black pines appeared wet when felled and a copious amount of resin was exuded from cut surfaces.

A few trees exhibited declining crowns and had very few or no pitch tubes above ground. These trees were excavated to a depth of $30 \mathrm{~cm}$. Extensive activity on the black turpentine beetle on the buttress roots was noted. Similar results were reported by Smith and Kowal (1968) on roots of slash pine. The patterns of discoloration appeared as an almost continuous band around the outer sapwood, rather than isolated wedges (Figure 4). Since this pattern did not extend above ground level it often went unnoticed and the important role of the fungus in 


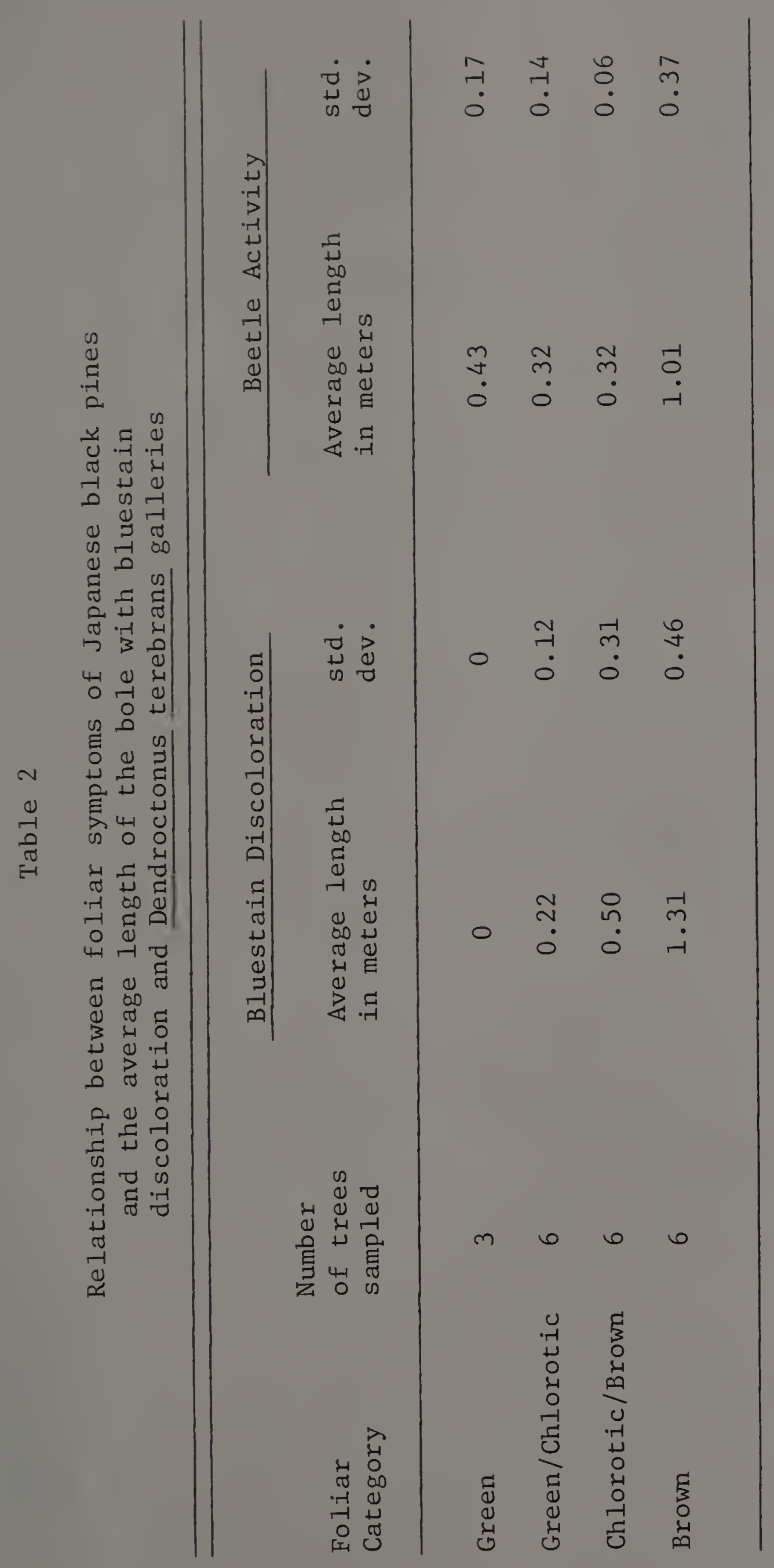




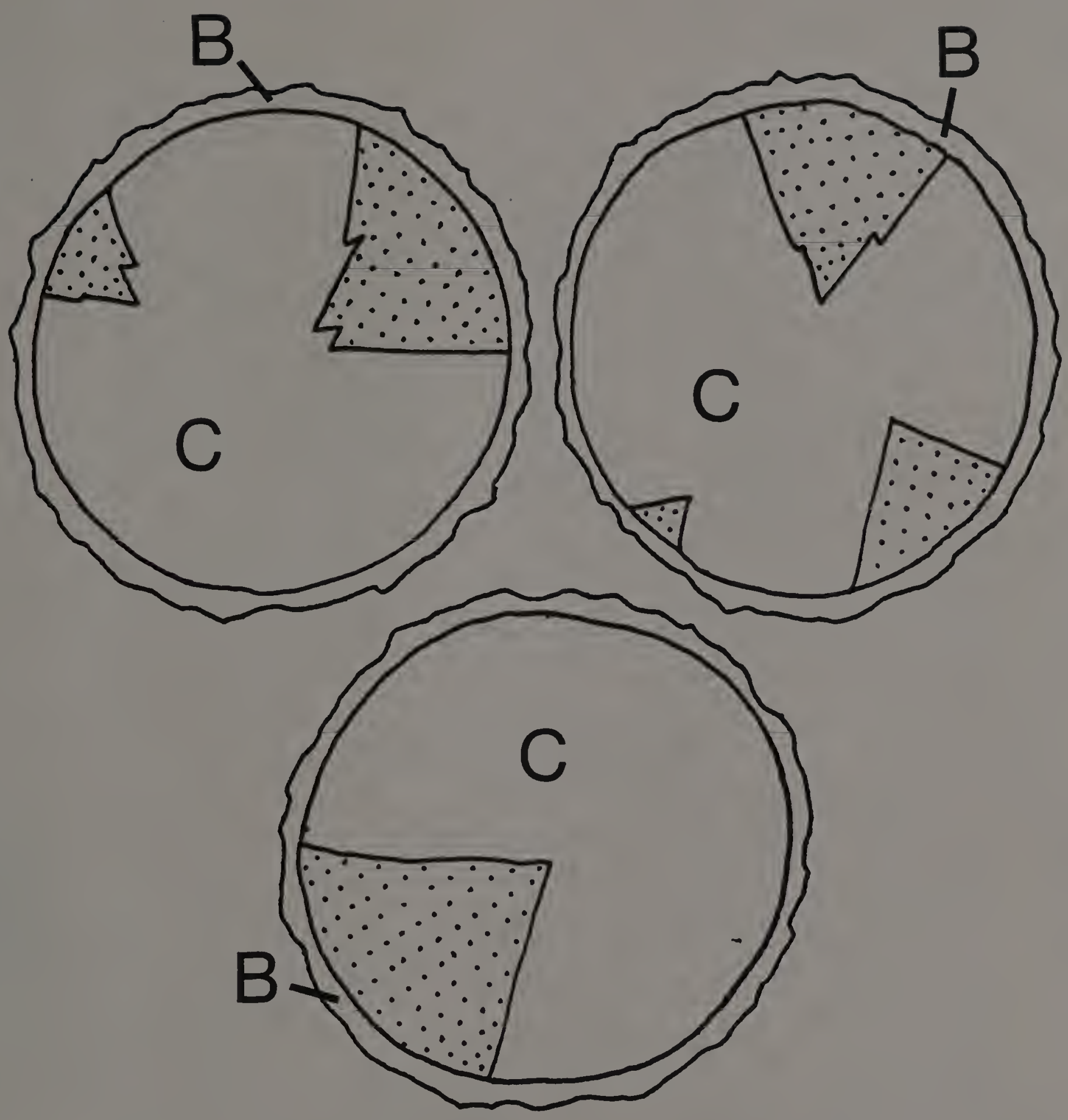

Figure 2. Typical cross-sectional views of bluestain discoloration patterns in the lower bole of Japanese black pines in late decline states. Bluestained wood (shaded area), clear wood (C), Bark (B). 


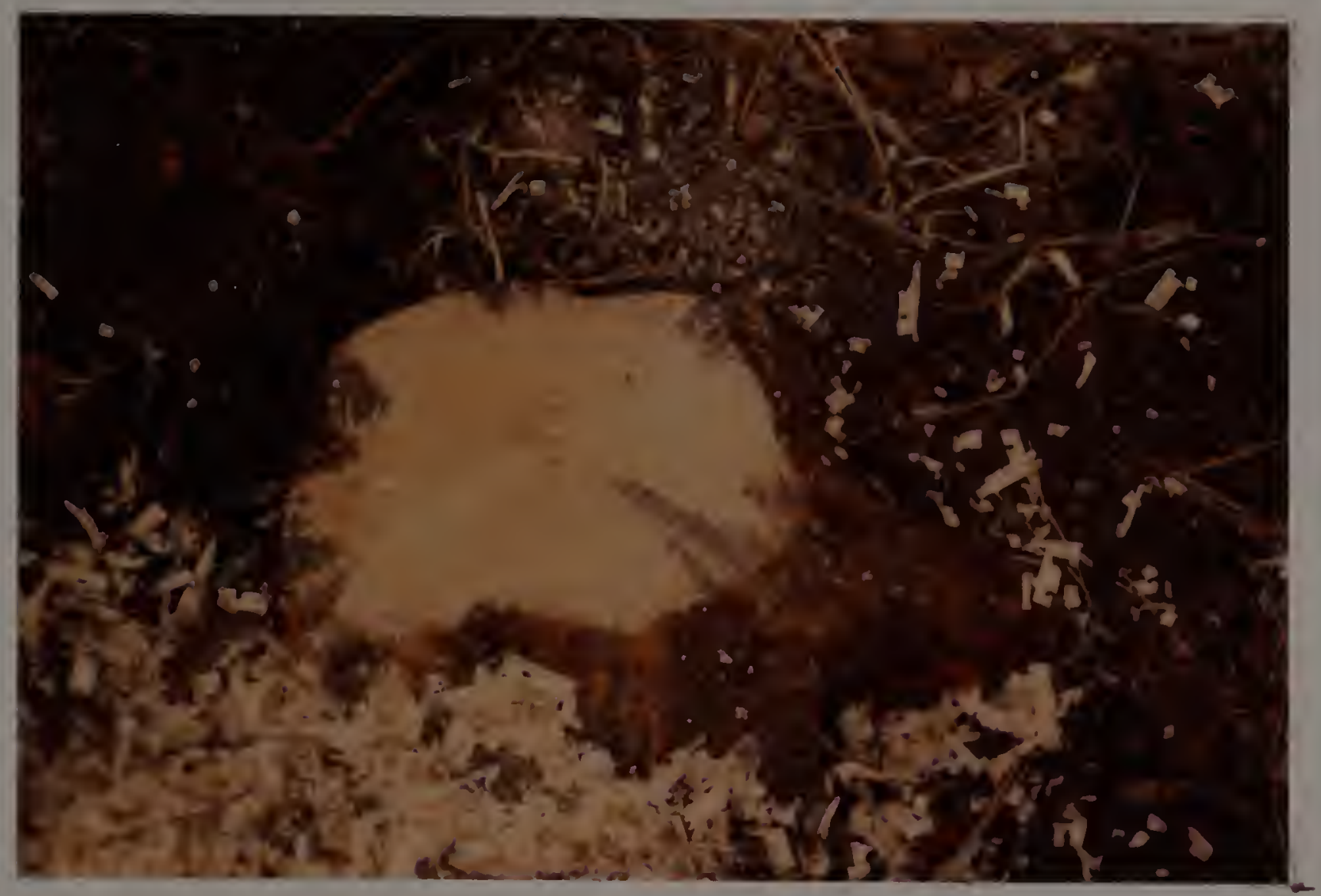

Figure 3. Cross-section of Japanese black pine lower bole showing the bluestain discoloration pattern.

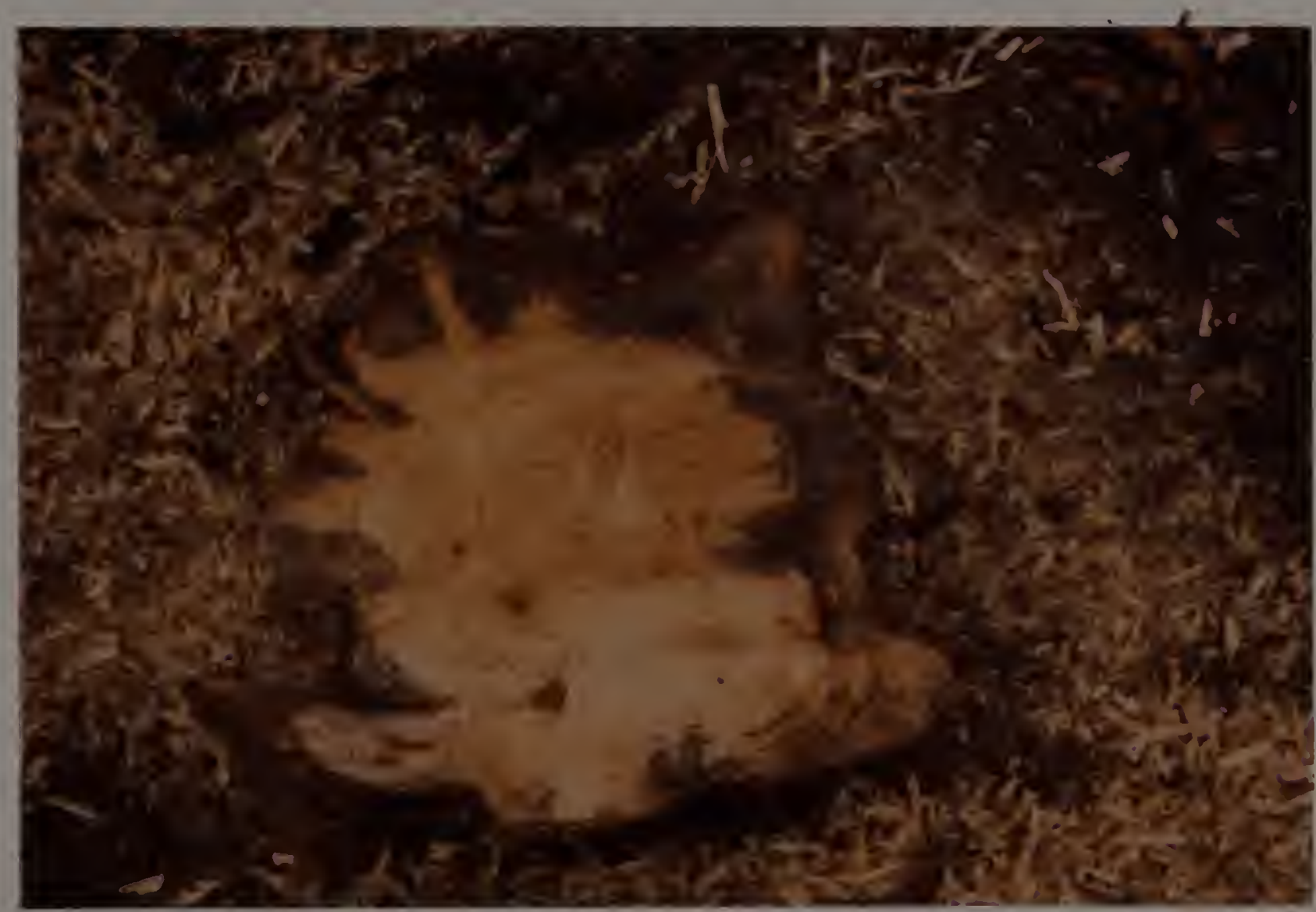

Figure 4. Cross-section of Japanese black pine buttress root zone cut $30 \mathrm{~cm}$ below ground showing the bluestain discoloration pattern. 
the death of these trees could be missed.

During the 1982 field season the amount of bluestain discoloration in the xylem was correlated with the trees' ability to break dormancy in the spring. Three trees were observed with buds that didn't break dormancy and had between 50 to $80 \%$ of the outer sapwood bluestained. Two trees were observed with buds that broke dormancy but no needle expansion occurred, these trees had 3 to $5 \%$ of the outer sapwood stained. In all five trees, black turpentine beetle activity was high. Ips activity was high in the trees that didn't break dormancy.

The roots of trees exhibiting brown foliage were examined and isolations made from the root buttress to determine if any soil-borne pathogens were involved in this disease progression. Tattar et al., (1980) did not isolate any pathogenic root fungi from symptomatic Japanese black pines on Cape Cod. I found two out of thirty trees (one Japanese black pine and one Scots pine) that had Armillaria mellea mycelial fans beneath the bark of the roots and the lower bole.

\section{$\underline{\text { Scots Pine }}$}

Field observations. Scots pines that were observed growing in a forest, were between 50 to 60 years old and in decline. The annual growth rate during the last 20 years averaged 8 to 12 annual rings per $\mathrm{cm}$. All symptomatic trees were attacked by the black turpentine beetle. The foliage of unattacked trees was sparse and the crowns appeared thin. After trees were attacked by the black turpentine beetle chlorosis occurred in a few branch tips, rather than uniformly throughout the crown 
as in Japanese black pines. After the entire crown turned chlorotic, browning randomly occurred in individual branch tips and gradually spread through the crown. The progression of symptoms was not as rapid as in Japanese black pines, some trees browned up in a few months, but most took a year to turn brown.

The stages of disease progression in Scots pines were classified by the foliar crown symptoms into the following four crown categories: (1) Green, (2) Green/chlorotic, (3) Chlorotic/brown, and (4) Brown. The green crown category included all trees with completely green foliage in the crown. The green/chlorotic crown category included trees in which approximately half of the branch tips were green and half were chlorotic. The chlorotic/brown crown category included trees in which approximately half of the branch tips were chlorotic and the other half were brown. The brown crown category included trees in which the entire crown was brown.

Al1 symptomatic Scots pines were heavily attacked ( $\geq 25$ pitch tubes per tree) by the black turpentine beetle on the lower bole. Attacks were also observed below ground on the buttress roots, but they were always in association with heavy lower bole attack. Light brown frass was also seen around the base of successfully attacked trees. The maximum percentage of cambial mining by the black turpentine beetle was considerably greater in Scots pines than in Japanese black pines (Tables 1 , 3). Scots pines were in a state of decline for a longer period of time and became attacked by heavy infestations of secondary bark beetles (Ips sp.) in the later stages of decline. Ips beetles were not present 


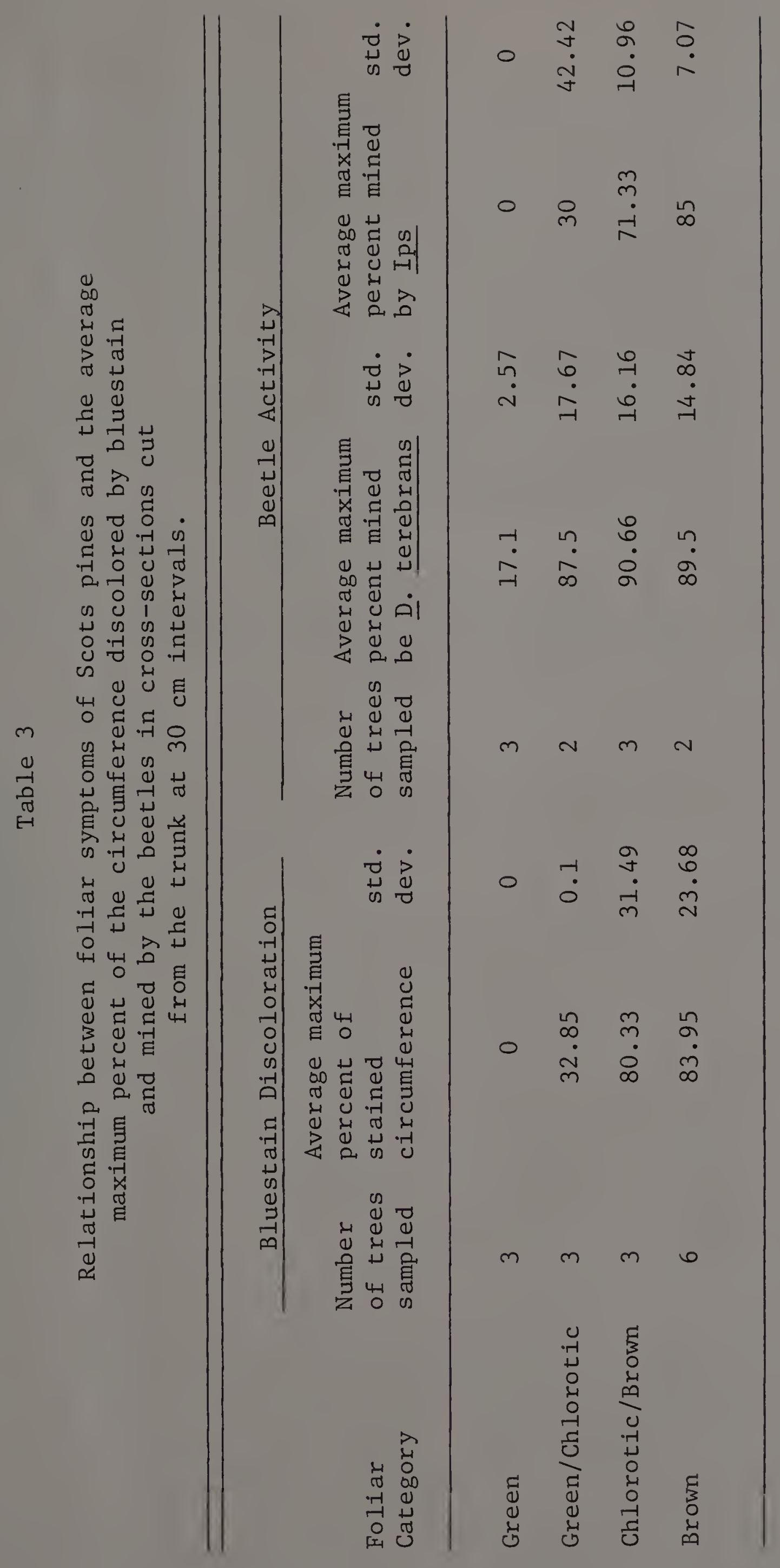


in trees attacked by the black turpentine beetle that still had green crowns.

Patterns of bluestain discoloration. There was a direct relationship between the percentage of circumferential bluestain and the crown condition (Table 3). Trees possessing green crowns had no bluestain in their sapwood. The percentage of circumferential bluestain increased as the foliar crown condition declined. A similar relationship occurred between the vertical length of the bluestain discoloration and the foliar crown symptoms. A substantial increase occurred between the vertical length of bluestain discoloration in the transition stages (green/chlorotic and chlorotic/brown) and the brown category (Table 4 ).

The patterns of discoloration occurring in Scots pines differed from those occurring in Japanese black pines. Scots pines had a clearly defined heartwood in contrast to Japanese black pines which did not. The bluestain did not appear as isolated wedges in the sapwood but rather as a continuous band (Figures 5,7 ). The amount of bluestained sapwood in trees in later stages of decline was higher than in Japanese black pines. Trees with brown crowns often had continuous bluestain columns extending the height of the tree. Trees in earlier stages of decline had discontinued columns of bluestain discoloration (Figure 9). The lower bole often possessed a large percentage of stained sapwood. The mid bole often had no bluestain discoloration and isolated narrow wedges occurred in the sapwood in the upper bole (Figures 6,8 ). These two distinct areas of bluestain discoloration were associated with 


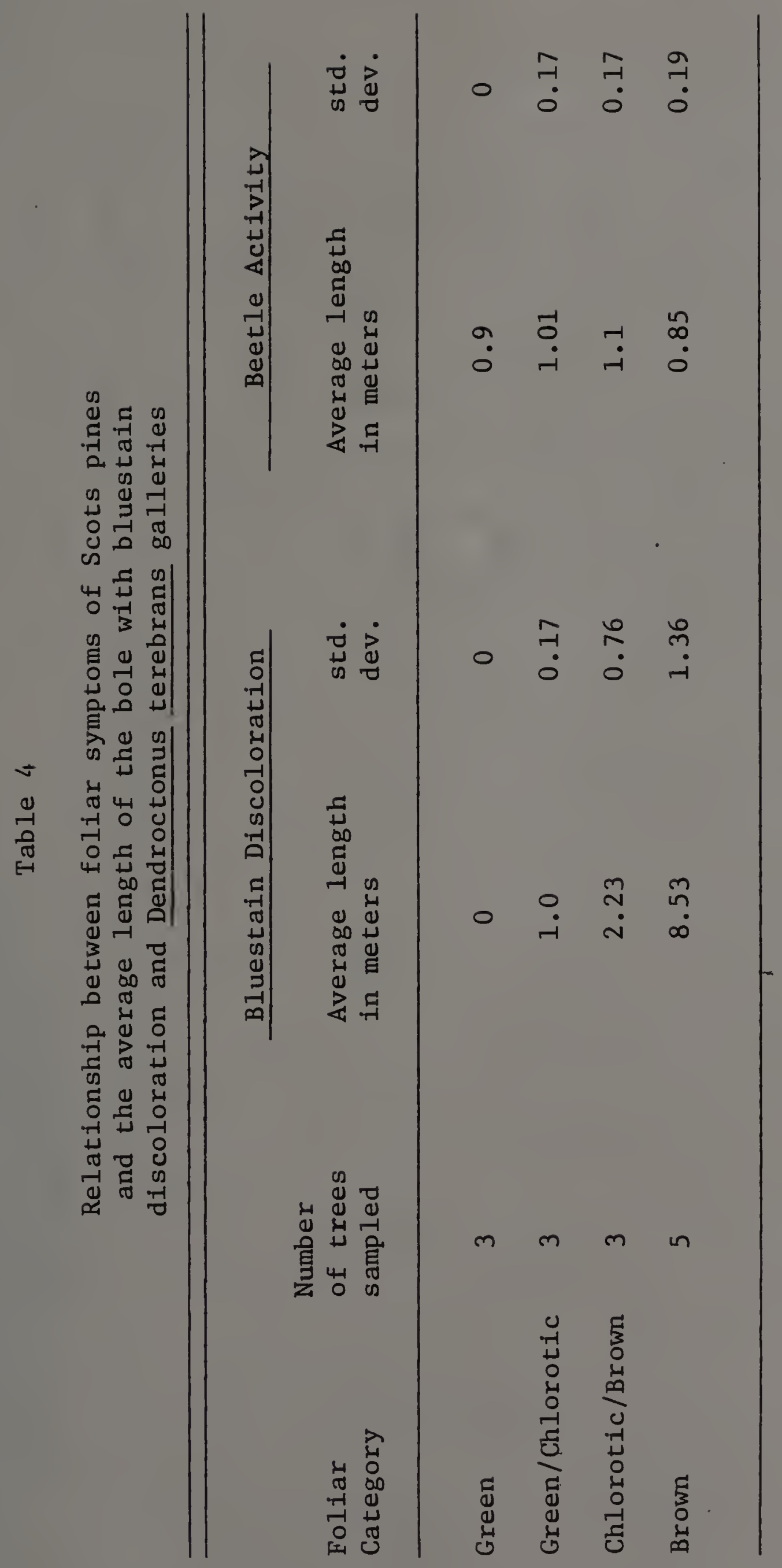




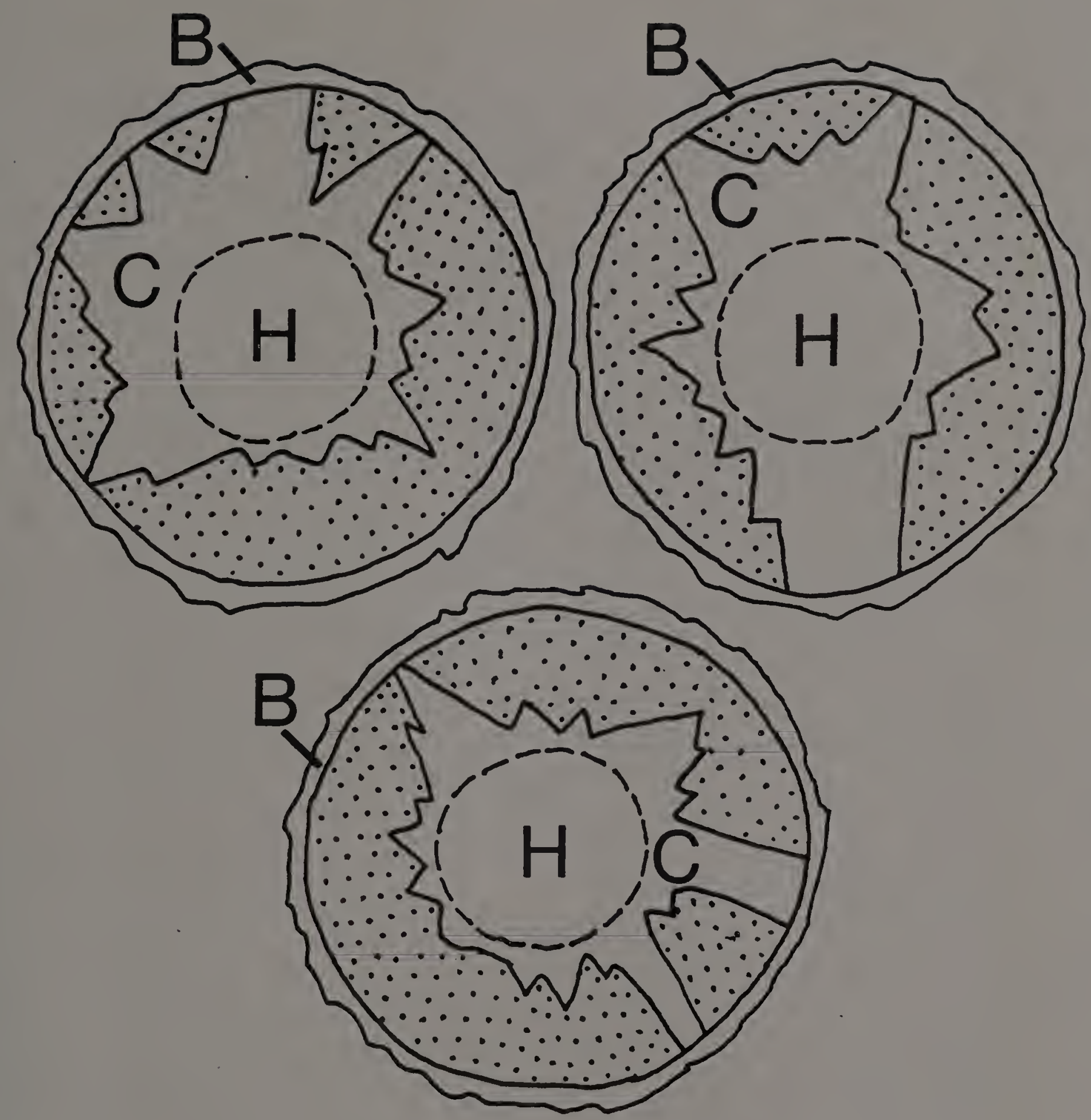

Figure 5. Typical cross-sectional views of bluestain discoloration patterns in lower bole of Scots pines in late decline stages. Bluestained wood (shaded area), Clear sapwood (C), Heartwood (H), Bark (B). 


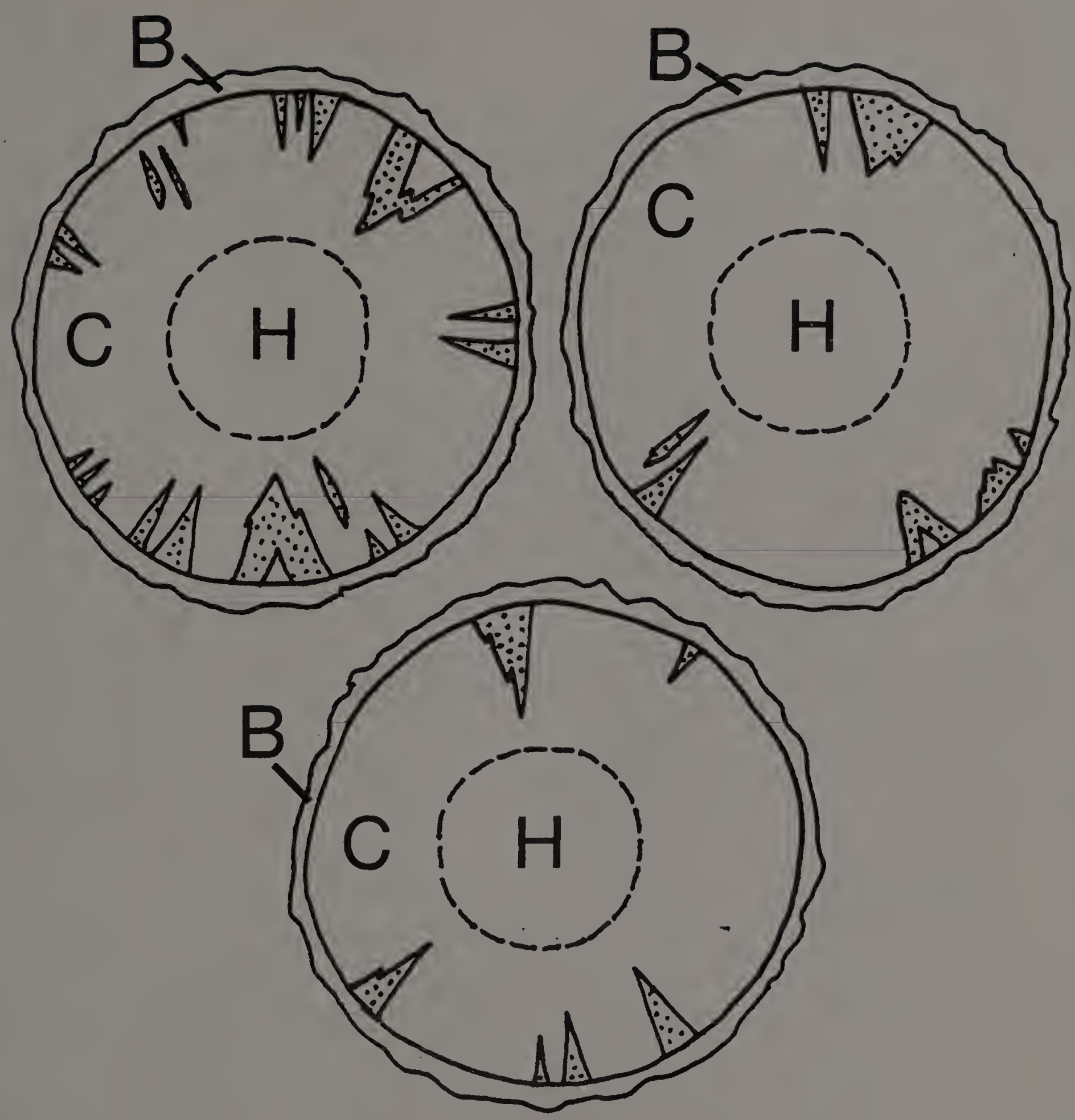

Figure 6. Typical cross-sectional views of bluestain discoloration patterns in upper bole of Scots pines in late decline stages. Bluestained wood (shaded area), Clear wood (C), Heartwood (H), Bark (B). 


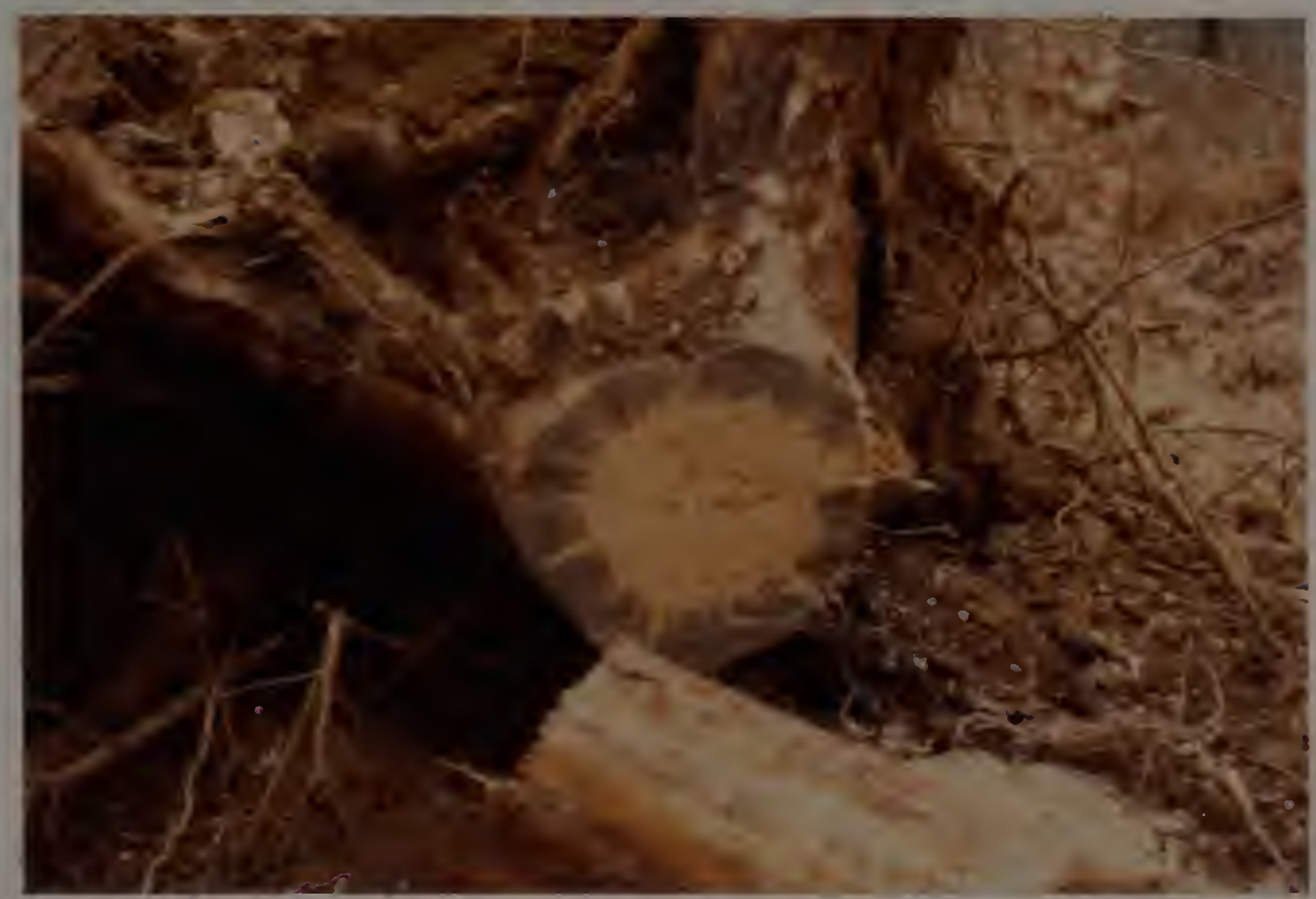

Figure 7. Cross-section of Scots pine lower bole showing the bluestain discoloration patterns.

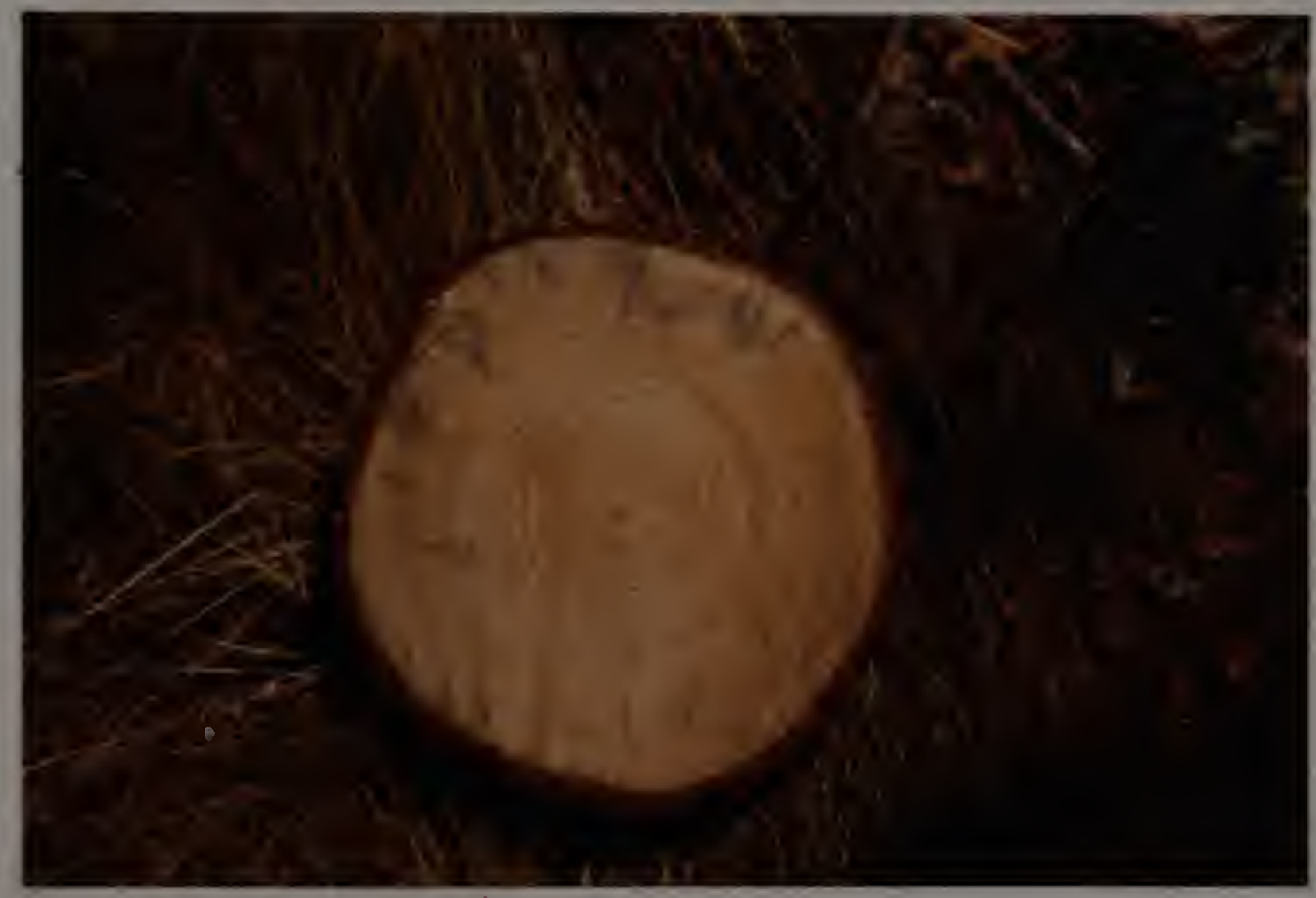

Figure 8. Cross-section of Scots pine upper bole showing the bluestain discoloration patterns. 
areas of beetle mining. Black turpentine beetles extensively colonized the lower bole and Ips beetles invaded the upper bole (Figure 9). Beetle attacks were not present in the mid bole around areas of clean sapwood. Resin soaked wood was not observed in cross-section of beetle attacked Scots pines and wood appeared dry when felled, very little resin was exuded from the cut surfaces.

\section{Isolations from Wood and Beetles}

Isolations from wood. Isolations of Leptographium were obtained from bluestained sections of sapwood. Bacteria and yeasts were occasionally isolated from discolored phloem surrounding beetle galleries. Leptographium was not recovered from resin soaked wood.

Colony growth of Leptographium on $2 \%$ Malt agar plates was fairly rapid, covering a $9 \mathrm{~cm}$ diameter petri plate in 10 days at room temperature. Conidial formation occurred rapidly, the conidial clusters first appearing white and turning honey colored with age. These conidial clusters on the surface of the blue-black mycelium gave the culture plate a speckled appearance. The fungus produced little or no aerial mycelium. Hyphae are brown and septate. The conidiophores are upright, single or in clusters and branched. The lower portion of the conidiophore is dark, but variable in shade, the upper portion is hyaline with penicillate branches. The sporogenous cells are slender and conidia are hyaline and ovoid. Conidial production is considered to be the distinguishing taxonomic characteristic between the genera Leptographium and Verticicladiella which appear similar in all other cultural charac- 


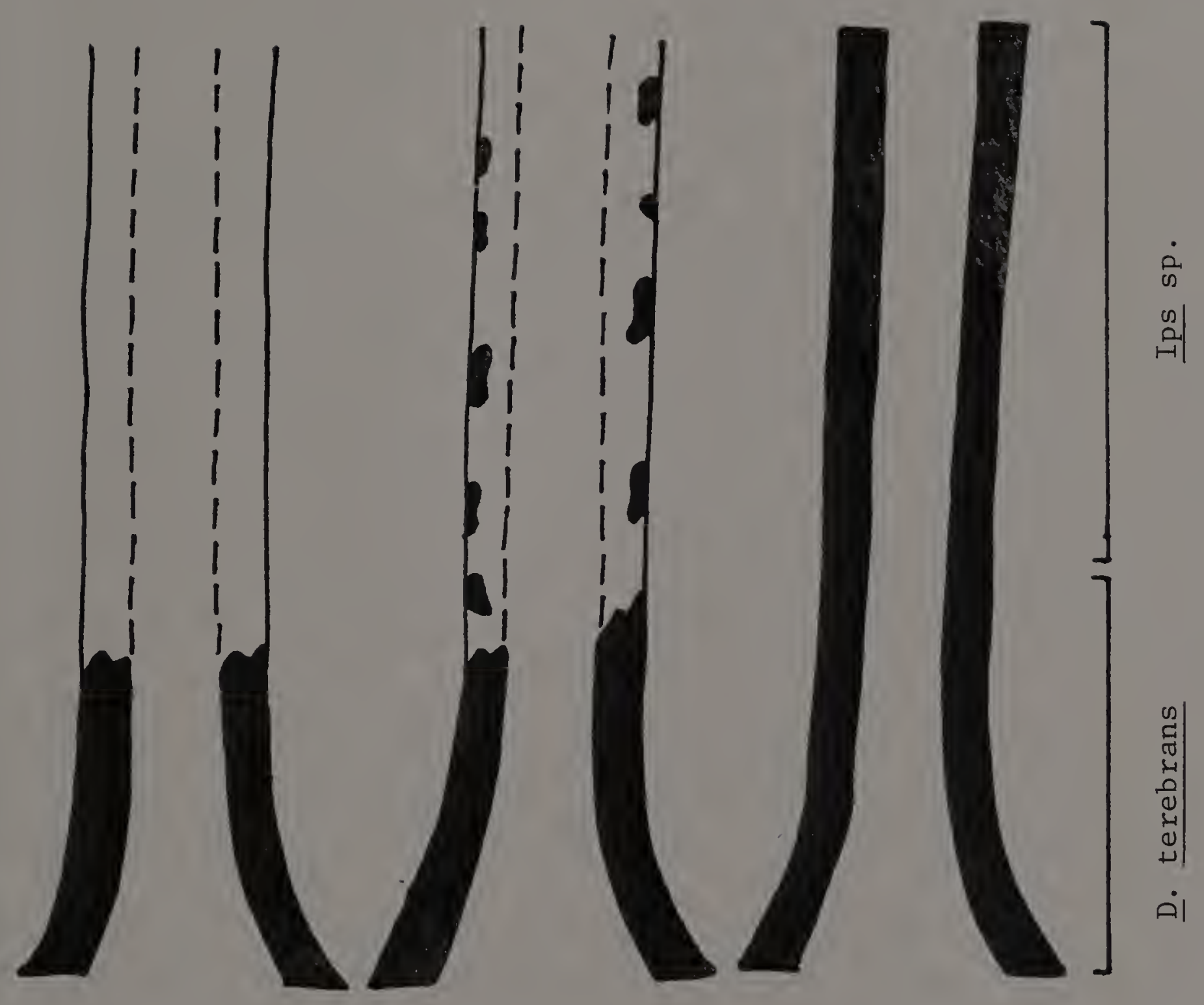

Figure 9. Typical vertical extent of bluestain discoloration in relation to the range of attack of Ips $\mathrm{sp}$. and Dendroctonus terebrans and the foliar crown symptoms of Scots pines. Brackets indicate attack range of respective beetles. Dashes indicate heartwood/sapwood transition. 
teristics. Conidia of Verticicladiella are sympodulospores in contrast to the annellospores of Leptographium.

Isolates obtained from bluestained wood appeared variable in their cultural appearance. The size of the conidiophores, however, differed greatly (Figure 10).

Nine isolates obtained from bluestained sapwood of both Scots and Japanese black pines were identified as Leptographium by Dr. C. J. K. Wang, SUNY College of Environmental Science and Forestry, Syracuse, NY; Dr. Dale Bergdahl, University of Vermont, Burlington, VT; and Dr. Michael Wingfield, University of Minnesota, St. Paul, MN. One isolate from Scots pine, however, was identified by Dr. Dale Bergdahl as Verticicladiella sp. Leptographium terebrantis associated with Dendroctonus terebrans was described by Barras and Perry (1971).

Cultures obtained from bluestained wood around Ips galleries had different mycelial characteristics. White, aerial mycelium covered the culture plates and the underside of the colony was blue-black. No conidiophores were produced from these cultures and they could not be identified.

It is suspected that all my isolates may be imperfect stages of Ceratocystis, however, no perithecia have been found in nature or produced in culture.

Isolations from beetles. Leptographium was recovered from isolations of sterilized and nonsterilized adult black turpentine beetles. Growth of Leptographium was not as abundant on cultures from nonsterilized bee- 


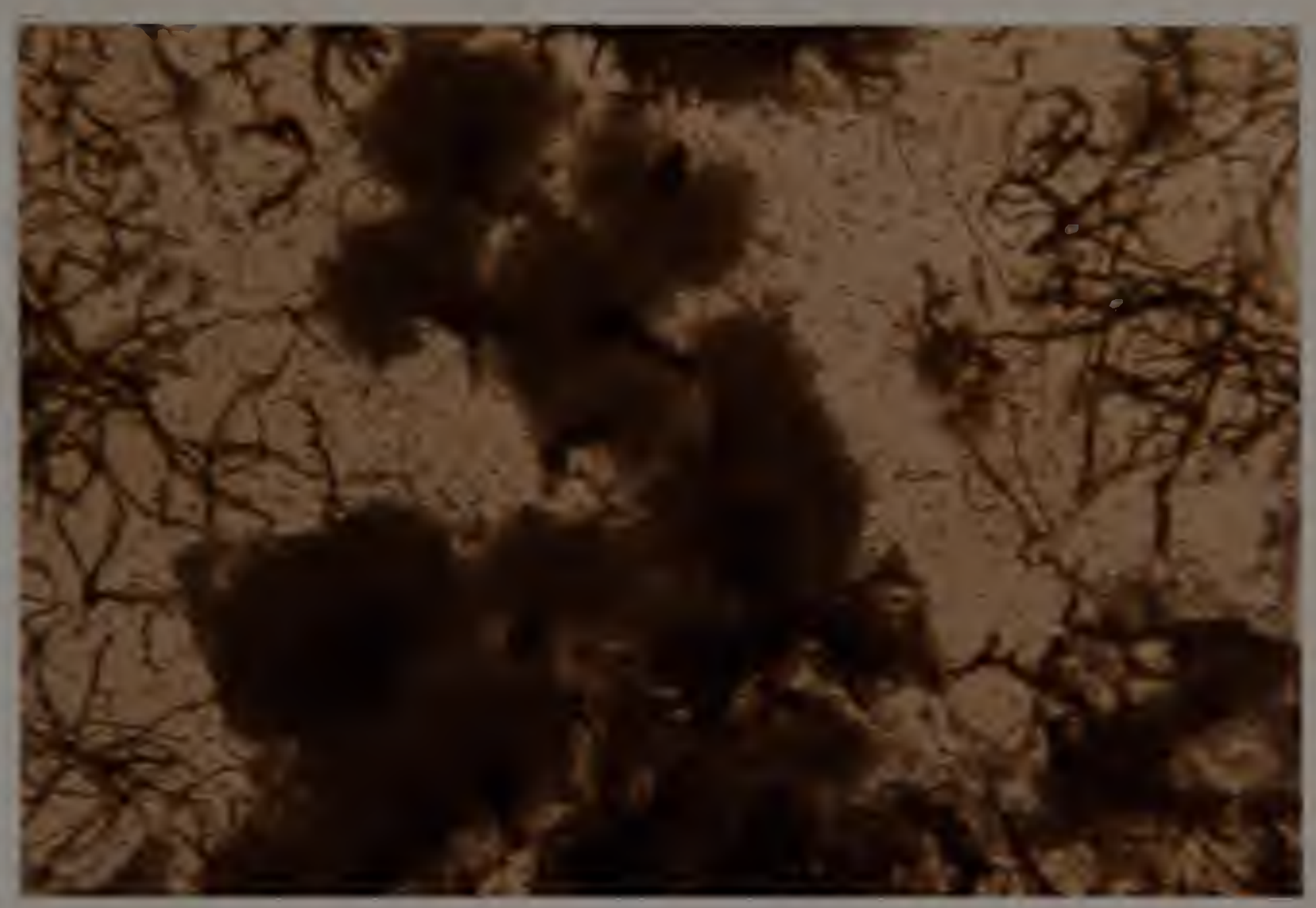

Isolate A $(x 100)$

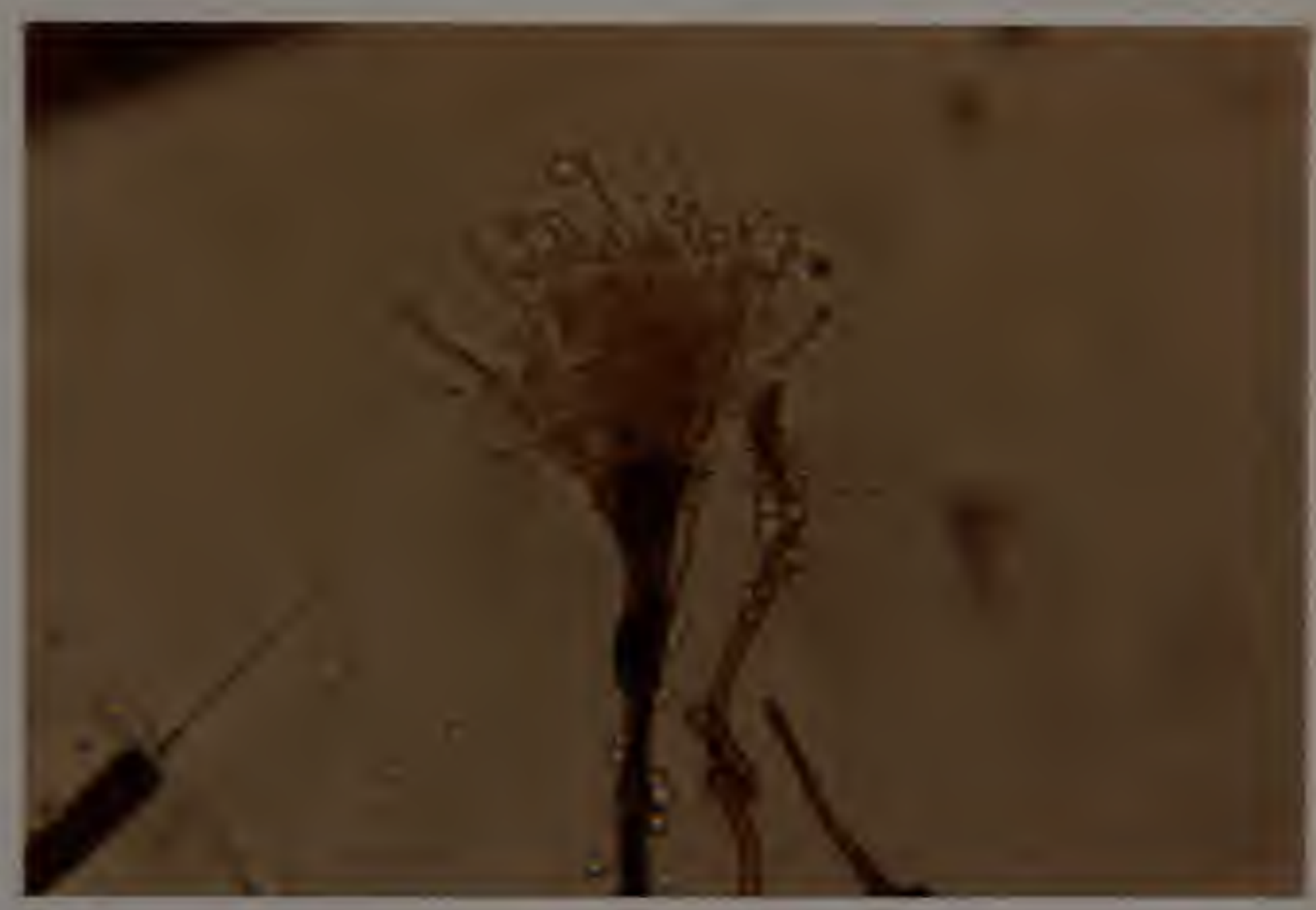

Isolate B (x430)

Eigure 10. Conidiopiores of Leptograpinium sp. isolates $A$ and $B$. 
tles, perhaps due to the growth of fungal contaminants and bacteria. Isolations made from black turpentine beetle eggs, larvae and pupae, however, did not yield Leptographium.

\section{Inoculation of Pines}

Inoculations of ten Scots pines and five Japanese black pines on Cape Cod and in Leverett, MA with Leptographium sp. isolates have not resulted in any foliar symptoms. Two inoculated Scots pines and two Japanese black pines on Cape Cod were harvested and dissected after three months. One Scots pine in Leverett was harvested and dissected after eight months.

Bluestain discoloration was not present in the wood or the phloem surrounding the inoculation site. Extensive resin soaking was associated with sites inoculated with Leptographium isolates (Figure 11). Scots pine harvested from Leverett also had a dark necrotic area surrounding the Leptographium-inoculated site. The resin soaked areas were elliptical in shape. Associated with the resin soaked wood, in trees harvested on Cape Cod (Table 5) were large pockets of crystallized and noncrystallized resin occurring beneath the outer annual rings. Cross-sectional cuts were made through the inoculation sites on these trees. Wedges of resin soaked wood similar to those associated with early black turpentine beetle attacks in Japanese black pines were observed.

Control sites inoculated with sterile agar showed little or no response (Table 5). Resin soaked wood was not observed in control sites of three of the four trees, however, one tree had a small resin soaked area but did not have a resin pocket. 


\section{Table 5}

Comparison of extent of resin soaked wood occurring around Leptographium inoculated sites and control sites on Japanese black pines and Scots pines on Cape Cod.

\begin{tabular}{lll}
\hline Pine Species & \multicolumn{2}{c}{ Resin soaked area in $\mathrm{cm}^{2}$} \\
\hline
\end{tabular}

Japanese Black Pine

Tree A

Tree B
12

0

Scots Pine

Tree A

Tree B

0

97.5 


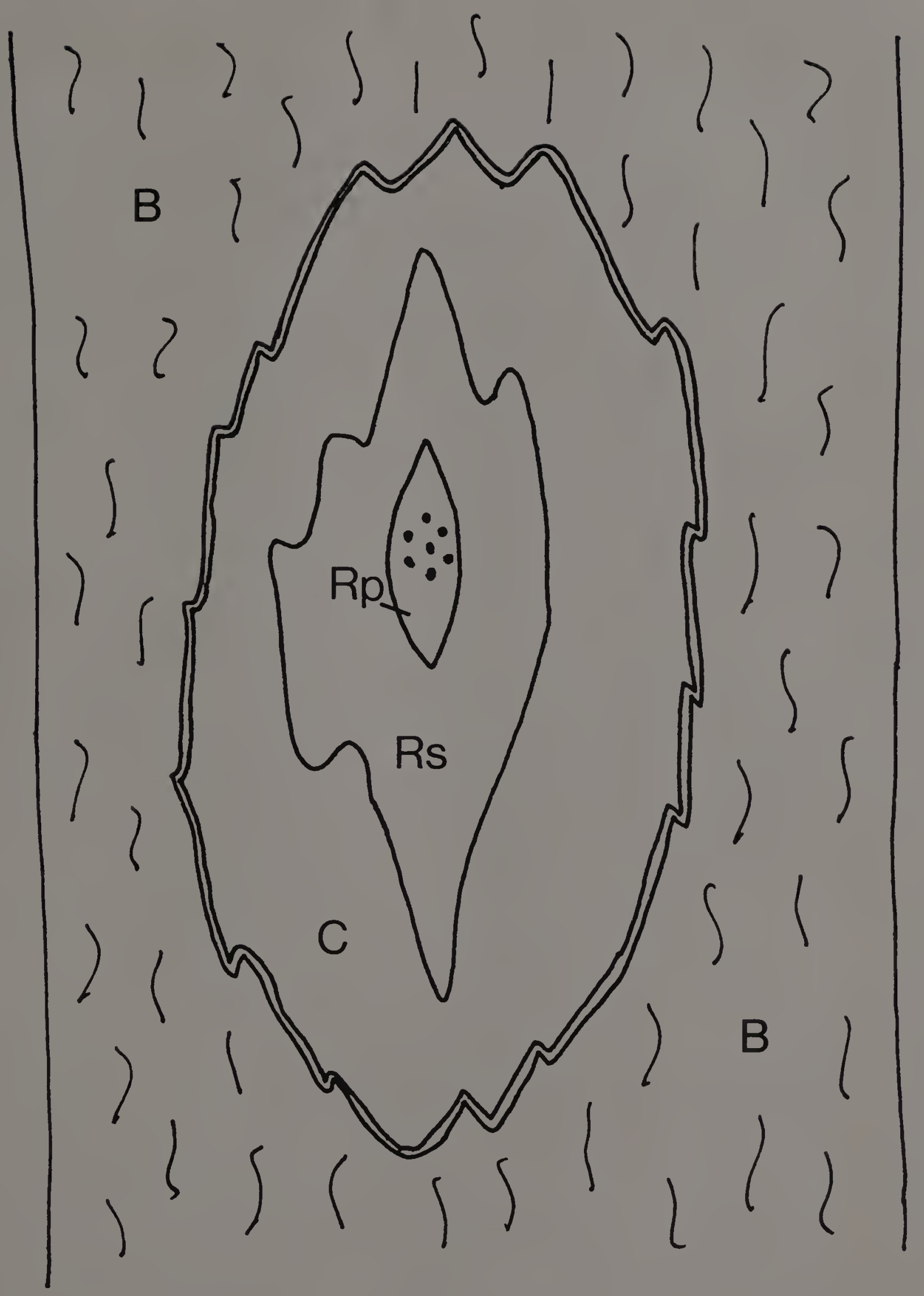

Figure 11. Typical host response of Japanese black pine and Scots pine to Leptographium inoculation. Resin soaked wood (Rs), Resin pocket (Rp), Inoculation sites (.), Healthy cambium (C), Bark (B). 


\section{H A P T E R IV}

\section{DISCUSSION}

Bluestain discoloration was present in all Scots and Japanese black pines on Cape Cod that had died following attack by the black turpentine beetle. A vector relationship between Dendroctonus beetles and bluestain fungi has been shown by many earlier researchers (Leach, 1934; Rumbold, 1931) and my isolations of Leptographium from the black turpentine beetle in these trees agree with those results.

The presence of the black turpentine beetle on Cape Cod has been known for several years (Becker, 1972). The damage occurring as a result of this bluestain-bark beetle association may have been unnoticed because of the characteristics of this beetle's attack. Scots and Japanese black pines are both exotic pine species, introduced to Cape Cod within the past 50 years, and may not be as well adapted to the environmental conditions on the Cape as the native species of pine. This may account for the susceptibility to attack of the black turpentine beetle on Scots and Japanese black pines.

This Dendroctonus terebrans-Leptographium association is expressed differently in these two pine species. The extent of black turpentine beetle attack was varied, Scots pines generally having a higher number of beetle attacks per tree than Japanese black pines. This could be attributed to the age and physiological condition of the Scots pines, bark beetles being more attracted to declining trees. The amount of bluestained xylem in Scots pines was higher than the amount in Japanese black pines. It might seem probable that since the Scots pines had a 
higher number of beetle attacks and a larger percentage of bluestained sapwood that they would decline more rapidly than the Japanese black pines. However, this was not the case; Japanese black pines declined more rapidly (2 to 3 months) than the Scots pines ( 1 year).

The vertical distribution of beetle attack should also be considered when comparing this disease on Japanese black pines and on Scots pines. Excavation of Japanese black pine roots revealed a high number of beetle attacks and also a large percentage of bluestained xylem. The girdling effect below ground could explain the rapid death occurring in trees with a small amount of bluestained sapwood in the lower bole. More thorough examination of the roots of Japanese black pines needs to be done to determine the extent of bluestained sapwood and beetle activity in that area.

Another factor that may hasten the death of Japanese black pines is the impregnation of cells with resin. Resin soaking occurs around early beetle attacks in Japanese black pines. Resin soaked wood has the same effect on stopping water conduction as bluestained wood. This resin response was not seen in Scots pines and may be due to their declining state.

The patterns of discoloration occurring in the sapwood can be related to the bark beetle, its gallery characteristics and the direction of fungal growth in the wood (Leach, 1934). Dendroctonus larvae, present in the lower bole, mine gregariously, inoculating a large surface of the sapwood and causing large, wide bluestain wedges in the xylem as the fungus invades inward along the rays. Ips larvae, in the upper 
bole, mine individually, inoculating a smaller surface area resulting in narrow bluestained wedges in the xylem. Since the fungi invade living xylem slowly tangentially, and move primarily along the rays, the type of gallery probably accounts for the patterns of xylem discoloration observed.

Discoloration patterns have also been correlated with the amount of beetle attack. Low numbers of beetle attacks on a tree resulted in discrete wedge-shaped patterns in cross-section (Harvey, 1979). Discrete bluestained wedges were present in Japanese black pines and these trees had lower numbers of beetle attacks than Scots pines. In Scots pines, where large numbers of beetles attacked individual trees, a continuous band of stained outer sapwood resulted from the coalescence of individual wedges.

Harvey (1979) showed a direct relationship between the amount of discoloration and the time after attack. This relationship was seen in the vertical length of the bluestain discoloration in the sapwood of Scots pines. Most dead Scots pines had bluestain discoloration occurring in uninterrupted columns the entire height of the tree. Trees in earlier stages of decline which were dissected often had broken columns of discoloration (Figure 9). The amount of time needed for the foliage to turn completely brown in Scots pines appeared also to be the time required for the bluestain discoloration columns associated with the black turpentine beetle to coalesce with the bluestain discoloration columns associated with the Ips beetles. Robinson (1962) reported a similar sequence of events occurring in lodgepole pines. $\underline{\text { D. ponderasae }}$ first 
attacked the tree, introduced early bluestain fungi and weakened the tree. Ips sp. attacked the weakened tree and introduced other bluestain fungi which resulted in completely bluestained sapwood.

This relationship between time following beetle attack and increase in bluestained sapwood, however, was not observed in Japanese black pines. This species had a more rapid rate of decline than Scots pines and were dissected shortly after the foliage turned brown. This was done as part of a sanitation program to save adjacent and nearby high value shade trees. Ips beetles were observed colonizing the upper boles of these trees but bluestain discoloration was not observed in the xylem. Bluestain fungi, however, was seen growing in the galleries. The time between the browning of the foliage and dissection may not have been adequate for the bluestain fungi from Ips beetles to colonize the xylem.

Isolations of bluestain fungi (Leptographium sp.) from stained sapwood have also been reported by Davidson, 1935, 1955; Robinson-Jeffrey and Grinchenko, 1964; Wright and Cain, 1961. However, some researchers have also isolated several other microorganisms colonizing the sapwood prior to or in association with bluestain fungi (Basham, 1959; Bramble and Holst, 1940; Caird, 1935). Using similar media and isolation techniques I was unable to isolate any other microorganisms from the sapwood. Bacteria and yeasts, however, were isolated from discolored phloem adjacent to beetle galleries. Bramble and Holst (1940) recorded the time period between beetle attack and isolation of microorganisms. They noted a difference in type, as well as abundance of microorganisms 
occurring at different time intervals. The bluestain fungi became more abundant with time. Most of my isolations were from trees in later stages of decline having abundant bluestain in their sapwood. More thorough isolations of trees in earlier decline stages need to be performed before the possible involvement of other organisms can be dismissed.

Conidial production is the sole taxonomic characteristic used to distinguish Leptographium from Verticicladiella. Observation of the annellations on Leptographium conidiophores was difficult using a light microscope. Therefore, no attempts were made to identify my isolates to species.

While inoculations of Scots and Japanese black pines in Leverett and on Cape Cod were not successful in reproducing foliar symptoms and death, a host response to Leptographium was observed. This response, a necrotic, resinous zone around the inoculation site, was similar to that seen in lodgepole pine attacked by Dendroctonus ponderosae and bluestain fungi (Reid et a1., 1967) and in Alpine fir attacked by Dryocoetes confusus (Molnar, 1964). Cross-sectional cuts through inoculation sites revealed wedges of resin soaked wood similar to those observed around initial unsuccessful beetle attacks in Japanese black pines. The response to fungal inoculations differed slightly between trees on Cape Cod and the trees in Leverett. The lack of resin pockets was present on the inoculated Scots in Leverett and could be related to the inoculation technique. More severe wounding preceded inoculation of trees on Cape Cod. The occurrence of little or no response around 
control sites indicates that a recognition factor may be involved in the trees' response. 
Anderson, R. F. 1948. Host selection by the pine engraver. Jour. Econ. Entomo1. 41:596-602.

Barnett, H. L. and B. B. Hunter. 1972. Illustrated Genera of the Imperfect Fungi. Burgess Pub. Co., Minn. $241 \mathrm{pp}$.

Barras, S. J. and J. D. Hodges. 1969. Carbohydrates of inner bark

of Pinus taeda as affected by Dendroctonus frontalis and associated microorganisms. Can. J. Bot. 101:489-493.

Barras, S. J. 1970. Antagonism between Dendroctonus frontalis and the fungus Ceratocystis minor. Ann. Entomol. Soc. Am. 63:1187-1190.

Barras, S. J. and T. Perry. 1971. Gland cells and fungi associated with prothoracic mycangium of Dendroctonus adjunctus (Coleoptera: Scolytidae). Ann. Entomol. Soc. Am. 64:123-126.

Barras S. J. and T. Perry. 1971. Leptographium terebrantis sp. nov. associated with Dendroctonus terebrans in loblolly pine. Mycopathol. et Myco. applic. 43:1-10.

Barras, S. J. and J. J. Taylor. 1973. Varietal Ceratocystis minor identified from mycangium of Dendroctonus frontalis. Mycopathol. et Myco. Applic. 50:293-305.

Basham, J. T. 1959. Studies in forest pathology. XX. Investigations of the pathological deterioration in killed Balsam fir. Can. J. Bot. $37: 291-326$.

Becker, W. B. 1972. The black turpentine beetle in southeastern Massachusetts. Mass. Co-op Extension Service Bulletin.

Berisford, C. W. and R. T. Franklin. 1971. Attack patterns of Ips avulsus and Ips grandicollis (Coleoptera:Scolytidae) on four species of southern pines. Ann. Entomol. Soc. Am. 64:894-897.

Berryman, A. A. 1972. Resistance of conifers to invasion by bark beetle-fungus associations. Bioscience 22:598-602.

Bramble, W. C. and E. C. Holst. 1940. Fungi associated with Dendroctonus frontalis in killing shortleaf pines and their effect on conduction. Phytopathology 30:881-899.

Caird, R. W. 1935. Physiology of pines infested with bark beetles. Bot. Gazette 96:709-733. 
Callaham, R. Z. and M. Shifrine. 1960. The yeasts associated with bark beetles. For. Sci. 6:146-154.

Clark, E. W. 1970. Attack height of the black turpentine beetle. Jour. Ga. Entomo1. Soc. 5:151-152.

Clements, R. W. and H. G. Williams. 1981. Attractants, Techniques, and Devices for Trapping Bark Beetles. USDA For. Serv. Note SE-309.

Coster, J. E., T. L. Payne and L. J. Edson. 1977. Aggregation of the southern pine beetle in response to attractive trees. Environ. Entomol. 6:725-731.

Craighead, F. C. 1925. Bark beetle epidemics and rainfall deficiency. Jour. of Econ. Entomol. 18:577-586.

Craighead, F. C. 1928. Interrelation of tree-killing bark beetles and bluestains. J. For. 26:886-887.

Craighead, F. C. and R. A. St. George. 1940. Field observations on the dying of pines infected with the bluestain fungus, Ceratostomella pini Munch. Phytopathology 30:976-979.

Davidson, R. W. 1935. Fungi causing stain in logs and lumber in the southern states, including five new species. Jour. Ag. Res. 50: $789-807$.

Davidson, R. W. 1955. Wood-staining fungi associated with bark beetles in Engelmann spruce in Colorado. Mycologia 47:58-67.

Davidson, R. W. 1958. Additional species of Ophiostomataceae from Colorado. Mycologia 50:661-670.

Davidson, R. W. 1978. Staining fungi associated with Dendroctonus adjunctus in pines. Mycologia 70:35-40.

Ellis, E. D. 1939. Ceratostomella ips associated with Ips lecontei in Arizona. Phytopathology $29: 556-557$.

Franklin, R. T. 1970. Observations on the bluestain-Southern pine beetle relationship. Jour. Ga. Entomol. Soc. 5:53-57.

Godbee, J. F., Jr. and R. T. Franklin. 1976. Attraction, attack patterns and seasonal activity of the black turpentine beetle. Ann. Entomol. Soc. Am. 69:653-6-5. 
Goheen, D. J. and F. W. Cobb. 1978. Occurrence of Verticicladiella wageneri and its perfect state, Ceratocystis wageneri sp. nov. in insect galleries. Phytopathology 68:1192-1195.

Graham, K. 1967. Fungal-insect mutualism in trees and timber. Ann. Rev. Entomol. 12:105-126.

Grosmann, H. 1932. Uber die systematischen Beziehugen der Gattung Leptographium Lagerberg et Melin zur Gattung Ceratostomella sacc. Hedwigia 72:183-194.

Harvey, R. D., Jr. 1979. Rate of increase of bluestained volume in mountain pine beetle killed lodgepole pine in northeastern Oregon, USA. Can. Jour. For. Res. 9:323-326.

Hetrick, L. A. 1949. Some overlooked relationships of southern pine beetles. Jour. of Econ. Entomol. 42:466-468.

Holst, E. C. 1936. Zygosaccharomyces pini, a new species of yeast associated with bark beetles in pines. Jour. Ag. Res. 53:513-518.

Hopping, G. R. and W. G. Mathres. 1945. Observations on outbreaks and control of the mountain pine beetle in the lodgepole pine stands of western Canada. For. Chron. 21:98-108.

Hughes, S. J. 1953. Conidiophores, conidia and classification. Can. J. Bot. 31:577-659.

Hunt, J. 1956. Taxonomy of the genus Ceratocystis. Lloydia 19:1-58.

Jooste, W. J. 1978. Leptographium reconditum sp. nov. and observations on conidiogenesis in Verticicladiella. Trans. Br. Mycol. Soc. $70: 152-155$.

Kaarik, A. M. 1960. Studies on the ecology, taxonomy and physiology of Swedish insect-associated bluestain fungi, especially the genus Ceratocystis. Oikos $11: 1-25$.

Kendrick, W. B. 1961. The Leptographium complex: Phialcephala gen. nov. Can. J. Bot. 39:1079-1085.

Kendrick, W. B. 1962. The Leptographium complex: Verticicladiella Hughes. Can. J. Bot. 40:771-797.

Knight, F. B. and H. J. Heikenen. 1980. Principles of Forest Entomology. McGraw-Hill Book Co., New York. 461 pp.

Lagerberg, T., G. Lundberg and E. Melin. 1927. Biological and practical researches into blueing in pine and spruce. Sv. Skogsvardsforen. Tidskr. 25:145-272. 
Leach, J. G. 1934. The interrelationships of bark beetles and bluestaining fungi in felled Norway pine timber. Jour. Ag. Res. 49: $315-341$.

Leaphart, C. D. 1960. A root stain disease of Eastern white pine. Plant Dis. Rept. 44:704-706.

Leaphart, C. D. and L. S. Gi11. 1959. Effects of inoculations with Leptographium sp. on Western white pine. Phytopathology 49:350-353.

Mathre, D. E. 1964. Survey of Ceratocystis spp. associated with bark beetles in California. Contrib. Boyce Thompson Inst. 22:353-362.

Mathre, E. D. 1964. Effects of Ceratocystis ips and Ceratocystis minor on the free sugar pool in ponderosa pine sapwood. Contrib. Boyce Thompson Inst. 22:509-512.

Mc Cambridge, W. F., G. D. Amman and G. C. Trostle. 1979. Mountain pine beetle. Forest Insect and Disease leaflet 2 . USDA.

Molnar, A. C. 1965. Pathogenic fungi associated with a bark beetle on Alpine fir. Can. J. Bot. 43:563-570.

Nelson, R. M. and J. A. Beal. 1929. Experiments with bluestain fungi in southern pines. Phytopathology 19:1101-1106.

Nelson, R. M. 1934. Effect of bluestain fungi on southern pines attacked by bark beetles. Phytopathology Z. 7:327-353.

Parker, A. K. 1957. Europhium, A new genus of the Ascomycetes with a Leptographium imperfect state. Can. J. Bot. 35:173-179.

Person, H. L. 1960. Theory in explanation of the selection of certain trees by the western pine beetle. J. For. 29:696-699.

Pollack, J. and R. Pollack. 1977. The pine killer. Colorado Outdoors 26:41-44. Reprint by USDA.

Reid, R. W. 1962. Biology of the mountain pine beetle, Dendroctonus monticolae Hopkins, in the East Kootenay region of British Columbia I. Life cycle, brood development and flight periods. Can. Entomol. $94: 531-541$.

Reid, R. W., H. S. Whitney and J. A. Watson. 1967. Reactions of lodgepole pine to attack by Dendroctonus ponderosae Hopkins and bluestain fungi. Can. J. Bot. 45:1115-1125.

Robinson, R. C. 1962. Bluestain fungi in lodgepole pine (Pinus contorta Dougl. var. latifolia enge1.) infested by the mountain pine beetle (Dendroctonus monticolae Hopk.) Can. J. Bot. 40:609-614. 
Robinson-Jeffrey, R. C. and A. H. H. Grinchenko. 1964. A new fungus in the genus Ceratocystis occurring on bluestained lodgepole pine attacked by bark beetles. Can. J. Bot. 42:527-532.

Rudinsky, J. A. 1962. Ecology of Scolytidae. Ann. Rev. Entomol. 7 : 327-348.

Rumbold, C. T. 1931. Two bluestaining fungi associated with bark beetle infestation of pines. Jour. Ag. Res. 43:847-873.

Rumbold, C. T. 1936. Three bluestaining fungi, including two new species, associated with bark beetles. Jour. Ag. Res. 52:419-437.

Rumbold, C. T. 1941. A bluestain fungus, Ceratostomella montium n. sp., and some yeasts associated with two species of Dendroctonus. Jour. Ag. Res. 62:589-601.

Sartwel1, C. and R. E. Stevens. 1975. Mountain pine beetle in ponderosa pine, prospects for silvicultural control in second growth stands. J. For. 73:136-140.

Shaw, C. G. and E. E. Hubert. 1952. A review of the LeptographiumScopularia - Hantzchia nomenclature. Mycologia 44:693-704.

Shigo, A. L. 1967. Successions of organisms in discoloration and decay of wood. International Review of Forest Research 2:237-299.

Shrimpton, D. M. and H. S. Whitney. 1967. Inhibition of growth of bluestain fungi by wood extractives. Can. J. Bot. 46:757-761.

Smith, R. H. 1957. Habits of attack by the black turpentine beetle on slash and longleaf pine in northern Florida. Jour. Econ. Entomol. 50:241-244.

Smith, R. H. and R. J. Kowal. 1968. Attack of the black turpentine beetle on roots of slash pine. Jour. Econ. Entomol. 61:1430-1432.

St. George, R. A. 1930. Drought-affected and injured trees attractive to bark beetles. Jour. Econ. Entomol. 23:825-829.

Tattar, T. A., R. A. Rohde, R. Mankowsky and H. D. Philbrick. 1980. Pine wilt associated with Leptographium sp.-black turpentine beetle complex in Japanese black and Scots pine (Abstr.). Phytopathology $71: 565$.

Vite, J. P. 1961. The influence of water supply on oleoresin exudation pressure and resistance to bark beetle attack in Pinus ponderosa. Contrib. Boyce Thompson Inst. 21:37-66. 
Vite, J. P. and R. G. Crozier. 1968. Studies on the attack behavior of the southern pine beetle. Contrib. Boyce Thompson Inst. 24: $87-94$.

Von Schrenk, H. 1903. The "blueing" and the "red rot" of the western yellow pine, with special reference to the Black Hills Forest Reserve. USDA Bureau of Plant Industry Bull. No. 36 .

Wagner, W. W. and J. L. Mielke. 1961. A staining fungus root disease of ponderosa, jeffrey and pinyon pines. Plant Dis. Rept. 45: $831-835$.

Whitney, H. S. and S. H. Farris. 1970. Maxillary mycangium in the mountain pine beetle. Science 167:54-55.

Whitney, H. S. 1971. Association of Dendroctonus ponderosae (Coleoptera:Scolytidae) with bluestain fungi and yeasts during brood development in lodgepole pine. Can. Entomol. 103:1495-1503.

Wood, D. L. and J. P. Vite. 1961. Studies on the host selection behavior of Ips confusus (Leconte) (Coleoptera:Scolytidae) attacking Pinus ponderosa. Contrib. Boyce Thompson Inst. 21:79-95.

Wright, E. F. and R. F. Cain. 1961. New species of the genus Ceratocystis. Can. J. Bot. 39:1215-1230.

Yearian, W. C., R. J. Gouger and R. C. Wilkinson. 1972. Effects of the bluestain fungus, Ceratocystis ips on development of Ips bark beetles in pine boles. Ann. Entomol. Soc. Am. 65:481-487. 
BLACK TURPENTINE BEETLE ACTIVITY

To monitor the activity of the black turpentine beetle two types of beetle traps were constructed. A sticky trap, consisting of an adhesive, "Tanglefoot," applied to $25 \mathrm{~cm}$ square pieces of $62 \mathrm{~cm}$ hardware cloth. The hardware cloth was attached to the tree at $30 \mathrm{~cm}, 90 \mathrm{~cm}$, and $150 \mathrm{~cm}$ and the adhesive applied with a metal scraper. Three trees in each of the four plots were chosen at random to be used. In the 1982 season aluminum flashing was substituted for hardware cloth in the sticky traps. Hardware cloth proved unacceptable because the beetles could mine through the adhesive and holes in the hardware cloth and attack the tree. The second type of trap was a turpentine-baited lure (Clements, 1981). This type consisted of a $120 \mathrm{~cm}$ diameter wading pool with a $120 \mathrm{~cm}$ section of stove pipe fastened in the center. The pool was filled to a depth of $12 \mathrm{~cm}$ with soapy water which served as a reservoir to collect the dead beetles. The stovepipe was baited with a turpentine in a plastic jar with a diffusion wick extending into a small cup. Virtually no beetles were trapped by either method. The sticky trap used in the 1981 field season was inadequate as explained above. The sticky traps used during 1982 field season were constructed in late July, after the main flight period of the black turpentine beetle. Sticky traps are most effective during the main flight periods of bark beetles; therefore, my traps were ineffective because of the time that they were constructed. The turpentine-baited lure traps were also ineffective in monitoring black turpentine beetle activity, perhaps due to 


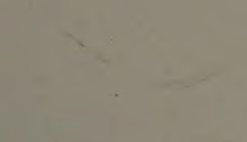

$x=3$

- $\quad+4$

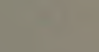


